\title{
NILAI FILOSOFIS, ETIKA DAN RITUAL BANGUNAN BALE DANGIN SAKENEM
}

\section{Arya Bagus Mahadwijati Wijaatmaja}

\author{
Program Studi Arsitektur Fakultas Teknik Universitas Dwijendra \\ aryabagus@undwi.ac.id
}

\section{Gusti Agung Laksmi Swaryputri}

\author{
Program Studi Ilmu Komunikasi Fakultas Ilmu Komunikasi Universitas Dwijendra \\ laksmiastawa@gmail.com
}

\begin{abstract}
Abstrak
Arsitektur tradisional Bali merupakan arsitektur daerah yang perlu dilestarikan pada era globalisasi ini. Pengetahuan dan implementasi mengenai arsitektur Bali juga semakin berkurang seiring pengaruh modernitas pada bangunan (arsitektur). Hal ini diikuti dengan kehadiran gaya arsitektur masa kini yang didominasi oleh arsitektur minimalis. Penerapan arsitektur bali dewasa ini hanya dapat ditemui pada penerapan ornamen-ornamen pada fasad bangunan semata.

Ada beberapa jenis bangunan Tradisional Bali yang masih bertahan sampai saat ini seperti bale dangin, bale meten/sakutus, bale dauh, jineng/kelumpu, paon dan lain-lain, bangunan tersebut masih bertahan dalam segi bentuk, fungsi, serta bahan-bahan yang digunakan sejak dahulu. Bale Dangin berfungsi sebagai tempat upacara, sehingga sangat vital keberadaannya bagi kehidupan masyarakat Bali yang bernafaskan agama Hindu. Maka dari itu perlu adanya usaha untuk melestarikan dan menjaga nilai-nilai budaya yang ada di dalamnya agar tidak hilang.

Penelitian mengenai Bale Dangin ini dilakukan berdasarkan atas kurangnya referensi yang membahas tentang bale dangin secara menyeluruh. Penelitian ini juga bertujuan untuk mengetahui kekhasan bangunan Bale Dangin Sakenem dilihat dari nilai filosofis, etika dan ritual, serta mendapatkan suatu bentuk pedoman yang diambil mengenai bangunan Bale Dangin Sakenem yang nantinya bisa dipakai acuan di dalam merancang atau mendirikan bangunan Bale Dangin Sakenem.

Pendekatan penelitian yang digunakan pada penelitian ini berdasarkan pada metode penelitian kualitatif deskriptif. Penelitian Kualitatif bermaksud untuk memahami fenomena tentang apa yang dialami oleh subjek penelitian misalnya perilaku, persepsi, motivasi, tindakan, secara holistik dan dengan deskripsi dalam bentuk kata-kata dan bahasa pada suatu konteks khusus yang alamiah dan dengan memanfaatkan berbagai metode alamiah. Metode penelitian kualitatif deskriptif pada penelitian ini digunakan untuk menggambarkan fakta-fakta yang ada di lapangan terkait dengan kondisi bale bale dangin sakenem pada studi kasus yang digunakan, dilihat dari fungsi bangunan, bentuk, tata letak, serta proses pembangunan mulai dari awal hingga bangunan tersebut siap untuk dihuni.

Penelitian ini diharapkan dapat menghasilkan referensi khusus mengenai bangunan bale dangin sakenem pada rumah tradisional bali dilihat dari nilai filosofis, etika dan ritual serta proses pembangunannya. Secara tidak langsung hal ini juga dapat melestarikan Arsitektur Bali yang sesuai dengan falsafah dan maknanya
\end{abstract}

Kata Kunci: Arsitektur tradisional, bale dangin, filosofis, etika, ritual

Abstract
Traditional Balinese architecture is a regional architecture that needs to be preserved in this
globalization era. The knowledge and implementation of Balinese architecture is also increasingly
diminished as the modernity influences the building (architecture). This is followed by the presence of
a present-day architectural style dominated by minimalist architecture. The application of Balinese
architecture today can only be found in the application of ornaments in the building façade.
There are several types of traditional Balinese buildings that still survive until now such as Bale
Dangin, Bale Meten/sakutus, Bale Dauh, Jineng/Kelumpu, Paon and others, the building is still
surviving in terms of shape, function, and materials used since the first time. Bale Dangin serves as a
place of ceremonies, so it is vital to the life of Balinese people who practice Hinduism. Therefore, it is
necessary to do the effort to preserve and keep the cultural values of Bale Dangin.
The research on Bale Dangin was conducted based on the lack of references that discussed the Bale
Dangin thoroughly. This research also aims to determine the peculiarities of the building of Bale 
Dangin Sakenem seen from philosophical value, ethics and ritual, and get a form of guidelines regarding the building of Bale Dangin Sakenem which can be used as reference in designing or constructing the Bale Dangin Sakenem building.

The research approach used in this research is based on qualitative descriptive research methods. Qualitative research intends to understand the phenomenon of what is experienced by research subjects such as behavior, perception, motivation, action, holistically and with descriptions in the form of words and language in a particular context that Nature and by utilizing a variety of natural methods. The method of descriptive qualitative research on this study was used to describe the facts in the field related to the condition of Bale Bale Dangin Sakenem in the case study used, judging by the function of building, form, layout, as well as Development process from the beginning until the building is ready to be occupied.

This research is expected to produce a special reference to the Bale building of the sakenem in a traditional Balinese house seen from the philosophical value, ethics and ritual and construction process. Indirectly, this can also preserve Balinese architecture that is in accordance with philosophy and meaning

Keywords: Traditional architecture, Bale dangin, philosophical, ethical, ritual

\section{PENDAHULUAN}

Arsitektur Bali merupakan perwujudan ruang dan wadah kehidupan masyarakat Bali yang mengikuti kaidah- kaidah yang diwariskan secara turun-temurun melalui literatur tradisional atau lontar, seperti: Asta Kosala-kosali, Asta Bumi, Asta Patali dan lainnya. Arsitektur Tradisional Bali yangbersumber pada falsafah, etika dan ritual agama Hindu, merupakan manifestasi budaya, dimana nilai-nilai dan kaidah-kaidah Bangunan Tradisional Bali sangat dipengaruhui oleh norma-norma agama Hindu, kearifan lokal serta cita rasa seni yang disesuaikan dengan kondisi masyarakat setempat. Arsitektur Tradisional Bali memiliki nilai-nilai filosofis, etika dan ritual yang pada hakikatnya bertujuan menciptakan keselarasan alam lingkungan demi keseimbangan hubungan manusia (mikrokosmos) dengan alam semesta (makrokosmos) dan Maha Pencipta. Arsitektur Bali dapat dibagi kedalam beberapa jenis bangunan yakni, bangunan Pura (tempat suci), hunian atau rumah tinggal, dan bangunan publik yang memiliki kaidah-kaidah pembangunan yang berbeda.

Arsitektur tradisional Bali khususnya hunian atau rumah tinggal tradisional merupakan arsitektur daerah yang perlu dilestarikan pada era globalisasi ini. Pengetahuan dan implementasi mengenai arsitektur Bali juga semakin berkurang seiring pengaruh modernitas pada bangunan (arsitektur). Hal ini diikuti dengan kehadiran gaya arsitektur masa kini yang didominasi oleh arsitektur minimalis. Penerapan arsitektur bali dewasa ini hanya dapat ditemui pada penerapan ornamen-ornamen pada fasad bangunan semata.

Ada beberapa jenis bangunan Tradisional Bali yang masih bertahan sampai saat ini seperti bale dangin, bale meten/sakutus, bale dauh, jineng/kelumpu, paon dan lain-lain, bangunan tersebut masih bertahan dalam segi bentuk, fungsi, serta bahan-bahan yang digunakan sejak dahulu. Bale Dangin berfungsi sebagai tempat upacara, sehingga sangat vital keberadaannya bagi kehidupan masyarakat Bali yang bernafaskan agama Hindu. Maka dari itu perlu adanya usaha untuk melestarikan dan menjaga nilai-nilai budaya yang ada di dalamnya agar tidak hilang.

Penelitian mengenai Bale Dangin ini dilakukan berdasarkan atas kurangnya referensi yang membahas tentang bale dangin secara menyeluruh. Penelitian ini juga bertujuan untuk mengetahui kekhasan bangunan Bale Dangin Sakenem dilihat dari nilai filosofis, etika dan ritual, serta mendapatkan suatu bentuk pedoman yang diambil mengenai bangunan Bale Dangin Sakenem yang nantinya bisa dipakai acuan di dalam merancang atau mendirikan bangunan Bale Dangin Sakenem.

Penelitian ini diharapkan dapat menghasilkan referensi khusus mengenai bangunan bale dangin sakenem pada rumah tradisional bali dilihat dari nilai filosofis, etika dan ritual 
serta proses pembangunannya. Secara tidak langsung hal ini juga dapat melestarikan Arsitektur Bali yang sesuai dengan falsafah dan maknanya.

\section{TINJAUAN PUSTAKA}

\subsection{Nilai Filosofis, Etika dan Ritual Arsitektur Tradisional Bali.}

Pendekatan konsep arsitektur tradisional Bali adalah konsep kehidupan masyarakat Bali yang dijiwai oleh ajaran agama Hindu yang disesuaikan dengan tempat, waktu dan kondisi (desa, kala, patra). Seperti halnya rumah, ajaran agama Hindu juga memilikki kerangka yang disebut Tiga Kerangka Dasar, yaitu:Tattwa (Filsafat), Susila (Etika) dan Upacara (Ritual). (Uthama, 2015: 27).

\subsubsection{Nilai Filosofis Arsitektur Tradisional Bali}

Tattwa (Filsafat) merupakan uraian filosofis tentang ajaran-ajaran yang tersimpul dalam Panca Sraddha (Lima Butir Keyakinan Umat Hindu), hubungan manusia dengan Tuhan, hubuungan manusia dengan sesama dan hubungan manusia dengan alam dan lingkungan. (Gorda, 199: 30). Arsitektur Tradisional Bali berusaha untuk mencapai keharmonisan antara aspek Ketuhanan (parhyangan), aspek manusia (pawongan), dan aspek lingkungan atau alam (palemahan). Keselarasan dan keharmonisan antara ketiga aspek ini disebut dengan Tri Hita Karana. (Uthama, 2015: 46)

Konsep Tri Hita Karana melandasi terwujudnya keselarasan kosmos dari Bhuana Agung dan Bhuana Alit. Pada tingkat desa dan banjar parhyangan diidentifikasikan dengan Pura Kahyangan Tiga dan Pura Banjar, pawongan diidentifikasikan dengan warga desa dan warga banjar, sedangkan palemahan diidentifikasikan sebagai wilayah desa dan wilayah banjar. Pada hunian, parhyangan diidentifikasikan sebagai sanggah pemerajan (tempat suci), pawongan diidentifikasikan sebagai penghuni rumah, dan palemahan diidentifikasikan sebagai pekarangan (Dwijendra, 2008).

Tabel 2.1. Konsep Tri Hita Karana pada Skala Perumahan dan Permukiman

Sumber: Wijaatmaja, 2018.

\begin{tabular}{|l|l|l|l|}
\hline Lingkup & Parhyangan & Pawongan & Palemahan \\
\hline Desa & Kahyangan Tiga & Warga Desa & Wilayah desa \\
\hline Banjar & Pura banjar & Warga Banjar & Wilayah banjar \\
\hline Hunian & Pemerajan & Penghuni & Pekarangan \\
\hline
\end{tabular}

Tri Hita Karana yang mengatur keseimbangan manusia dengan alam, tersusun dalam susunan badan material (angga) yang menurunkan konsep ruang yang disebut Tri Angga (tiga badan), yang menekankan pada tiga nilai fisik, yaitu: Utama Angga (kepala), Madya Angga (badan) dan Nista (kaki). Konsep Tri Angga ini berlaku dari skala makro dan mikro.

Tabel 2.2 Konsep Tri Angga dalam Skala Perumahan, Pemukiman dan Bangunan Sumber: Dwijendra, 2008.

\begin{tabular}{|l|l|l|l|}
\hline Lingkup & Utama Angga & Madya Angga & Nista Angga \\
\hline Perumahan/Desa & Kahyangan Tiga & Pemukiman & Setra/Kuburan \\
\hline Rumah Tinggal & Sanggah/Pemerajan & Tegak Umah & Tebe \\
\hline Bangunan & Atap & Kolom/dinding & Lantai/bebatuan \\
\hline
\end{tabular}

Selain memberikan nilai secara vertikal, Tri Angga juga memiliki tata nilai HuluTeben, yang merupakan tata nilai dalam mencapai keselarasan antara bhuana agung (alam semesta) dan bhuana alit (manusia). Konsep Hulu-Teben ini mempunyai beberapa orientasiorientasi, antara lain: 1) Orientasi dengan konsep sumbu ritual kangin-kauh (timur-barat), kangin (matahari terbit) sebagai hulu dan kauh (matahari terbenam) sebagai teben; 2) Orientasi dengan konsep sumbu bumu/natural kaja-kelod (utara-selatan), kaja (ke arah gunung) sebagai hulu dan kelod (ke arah laut) sebagai teben; serta 3) Orientasi dengan 
konsep Akasa-Pertiwi (atas-bawah), Konsep Akasa-Pertiwi diterapkan dalam perumahan atau lingkungan di Bali dikenal dengan natah. (Dwijendra, 2008: 6).

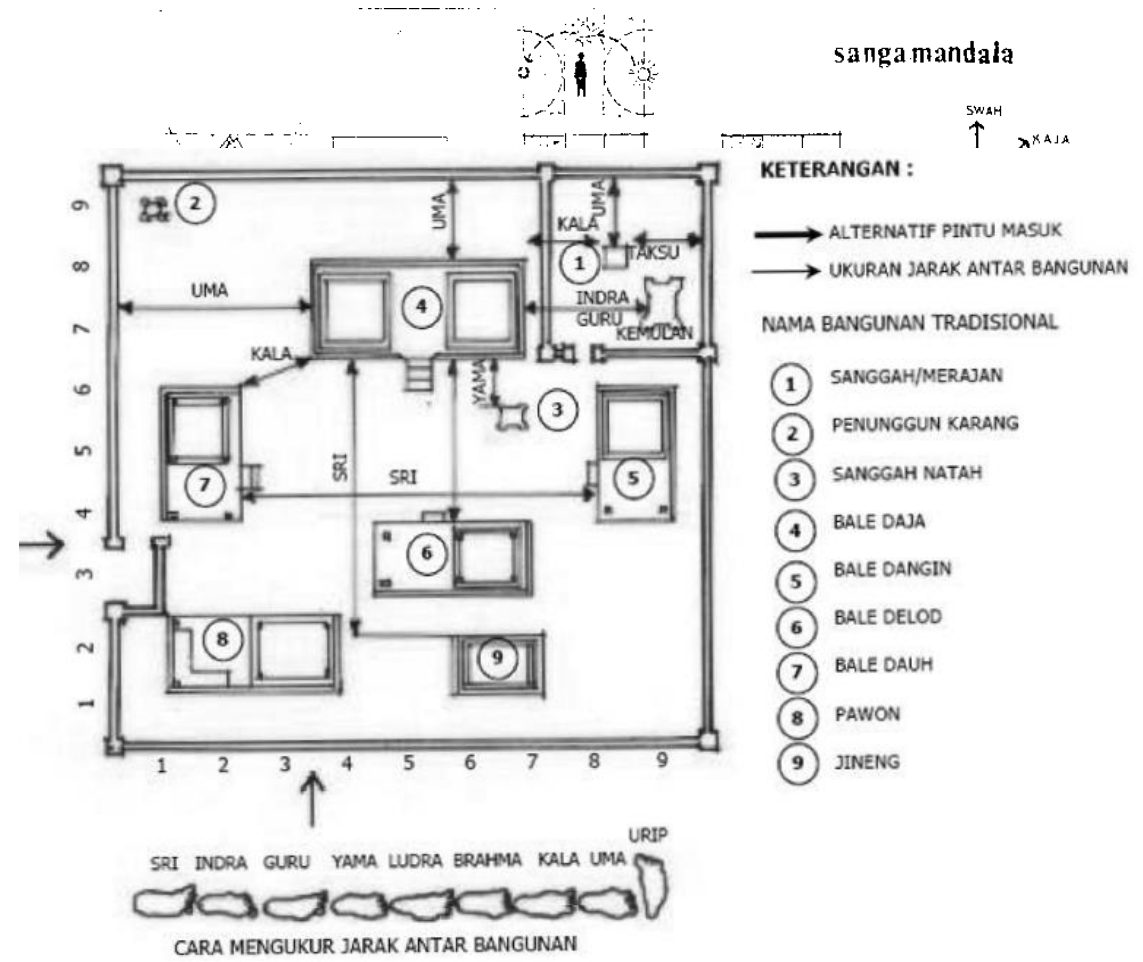

Gambar 2.2 Pola Ruang Hunian Tradisional Bali \& Pengukuran Jarak antar Bangunan

Sumber: Adhika, 1994.

. Konsep Sanga Mandala menjadi pertimbangan dalam penzoningan kegiatan dan tata letak bangunan. Suatu pekarangan hunian perumahan tradisional dibagi menjadi 9 bagian utama. Zone kaja-kangin diperuntukkan sebagai area suci (parhyangan), zone tengah untuk pawongan, ruang-ruang perumahan serta zone nista, kauh-kelod, untuk pelayanan yang disebut palemahan atau lebih. (Gelebet, 1986).

\subsubsection{Nilai Etika Arsitektur Tradisional Bali}

Etika (Susila) terbentuk dari seperangkat nilai dan norma perilaku yang bersumber secara langsung atau tidak langsung dari tattwa. Etika mengatur perilaku manusia dalam upayanya untuk mencapai tujuan dan hakikat hidup. Dengan demikian, etika menjelaskan dan mendefiniskan apa yang benar dan apa yang salah, apa yang baik dan apa yang buruk dalam perbuatan manusia, berdasarkan filsafat (tattwa). (Gorda, 1996: 35). Etika dalam Arsitektur tradisional Bali mencakup kaidah-kaidah dan tata cara tentang apa yang harus dilakukan dan/atau dihindari dalam proses pembangunan suatu bangunan. Tata cara pembangunan meliputi: pemilihan lahan (Anon., t.thn.), kaidah pemilihan dan pengolahan bahan (Lontar Asta Kosali dan Lontar Wiswakarma), kaidah dimensi dan ukuran serta kaidah konstruksi.

\subsubsection{Nilai Ritual Arsitektur Tradisional Bali}

Ritual (upacara) sebagai kerangka dasar yang ketiga, merupakan rangkaian kegiatan manusia dalam upaya berkomunikasi dengan Tuhan, leluhur dan alam sekitar (Gorda, 1996: 38). Ritual merupakan kualitas etika yang dilandasi dengan pendekatan upacara yang baik dan benar.

Ritual dalam pembangunan bangunan tradisional Bali meliputi upacara menanggulangi "cacat" pekarangan, upacara nyukat karang, upacara nyapuh dan nyakap 
karang, upacara sebelum menebang kayu, upacara memotong dan membelah kayu, upacara ngeruak, upacara nasarin (peletakan batu pertama), upacara ngauk sunduk, upacara membuat galar, upacara memakuh, upacara memasang usuk dan mengatapi, serta upacara pemelaspas (peresmian)

\subsection{Tinjauan Bale Dangin Sakenem}

Bale dangin sakenem berfungsi sebagai tempat mempersiapakan kegiatan upacara keagamaan terutama upacara manuasia yadnya dan pitra yadnya. Bale Dangin terletak di bagian timur (dangin) dalam suatu pekarangan rumah (natah). Bale dangin memiliki enam tiang penyangga (sakenem). Perletakan sakenem tersebut yaitu, empat tiang pada satu balebale dan dua tiang di teben. Bangunan tertutup dua sisi terbuka kearah natah, Konstruksi atap atap dengan limasan dengan puncak dedeleg, penutup atap alang-alang atau genteng. (Dwijendra, 2008: 127).

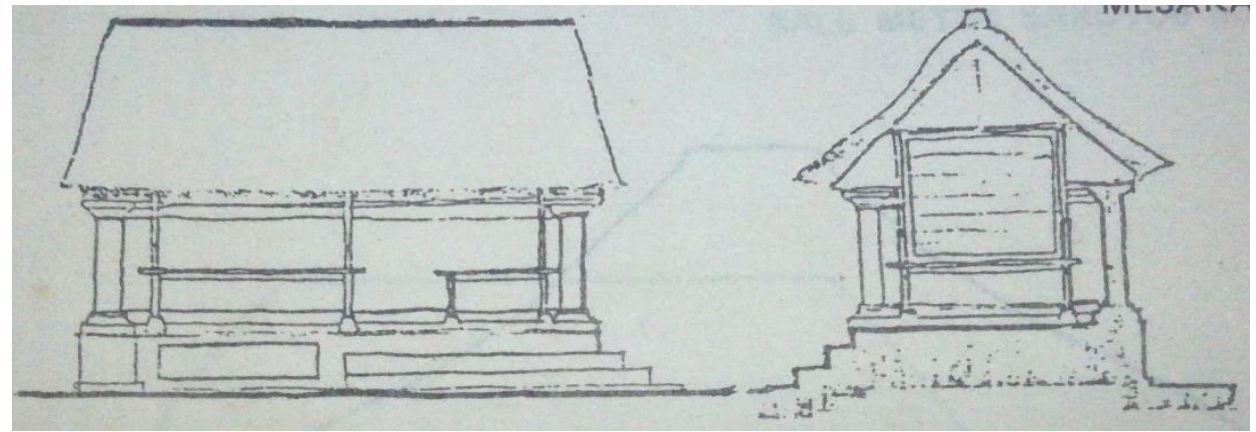

Gambar 2.3 Bentuk bangunan bale dangin sakenem

\section{Sumber: Gelebet, 1986.}

\subsubsection{Struktur Bale Dangin Sakenem}

Sistem struktur yang digunakan pada Bale Dangin Sakenem adalah sistem struktur rangka yang bentangnya masih cukup kecil, sehingga beban yang diakibatkan oleh beratnya sendiri masih relatif kecil.

\section{a. Sub Struktur}

Bagian bawah atau kaki bangunan disebut dengan bebaturan yang terdiri atas jongkok asu sebagai penghubung tiang dengan pondasi, dan tapas hujan sebagai perkerasan tepi bebaturan.

\section{b. Super Struktur}

\section{1) Dinding}

Bahan dari dinding pada bale dangin sakenem jaman dulu biasanya menggunakan tanah polpolan, namun seiring perkembangan jaman, bahan dinding yang biasa digunakan saat ini yaitu, bata merah dan batu paras, bahkan terkadang diplester dengan semen.

\section{2) Tiang/Sesaka}

Kedudukan tiang distabilkan oleh elemen-elemen pengakunya. Untuk tiang-tiang yang menyangga bale kedudukan distabilkan oleh sunduk, waton dan likah.

\section{c.Upper Struktur}

Pada umumnya bale dangin sakenem menggunakan bentuk atap limasan. Konstruksi atap bale dangin sakenem terdiri atas beberapa bagian sebagai berikut:

\section{1) Iga-Iga}

Usuk-usuk bangunan tradisional Bali disebut dengan iga-iga. Pangkal iga-iga dirangkai dengan kolong/dedalas yang merupakan bingkai tepi luar atap dan ujung atasnya menyatu dengan puncak atap.

\section{2) Pemade}


Merupakan iga-iga yang menempati tiang-tiang ditengah bangunan. Bahan umumnya menggunakan seseh.

3) Ретиси

Ретиси menempati sudut-sudut atap ke tiang-tiang sudut. Bahan umumnya menggunakan seseh.

4) Apit-apit

Merupakan konstruksi bidang atap yang mengikat iga-iga.

5) Grantang

Terletak pada bagian bawah untuk mendapatkan bidang atap dengan kemiringan di bagian bawah lebih kecil dari bagian atas.

6) Pementang

Balok tarik yang membentang di tengah-tengah dan mengikat jajaran tiang tengah.

7) Sineb Lambang

Balok belandar sekeliling rangkaian tiang-tiang tepi dalam bangunan tradisional Bali disebut lambang. Sedangkan lambang rangkap yang disatukan oleh balok disisi bawahnya disebut sineb.

8) Tadapaksi

Balok tarik yang mengikat pementang berakhir di atas tiang tengah. Tadapaksi dan pementang merupakan balok tarik yang menstabilkan lambang sineb dan tiang-tiang penyangga.

9) Tugeh

Tiang penyangga konstruksi atap.

10) $R a a b$

Penutup atap tradisional Bali disebut raab yang umumnya dibuat dari bahan-bahan alam, seperti alang-alang.

\section{METODE}

Pendekatan penelitian yang digunakan pada penelitian ini berdasarkan pada metode penelitian kualitatif deskriptif. Penelitian Kualitatif bermaksud untuk memahami fenomena tentang apa yang dialami oleh subjek penelitian misalnya perilaku, persepsi, motivasi, tindakan, secara holistik dan dengan deskripsi dalam bentuk kata-kata dan bahasa pada suatu konteks khusus yang alamiah dan dengan memanfaatkan berbagai metode alamiah (Moleong, 2008). Metode penelitian kualitatif deskriptif pada penelitian ini digunakan untuk menggambarkan fakta-fakta yang ada di lapangan terkait dengan kondisi bale dangin sakenem pada studi kasus yang digunakan, dilihat dari nilai filosofis, etika dan ritual, serta proses pembangunan mulai dari awal hingga bangunan tersebut siap untuk dihuni.

\section{HASIL DAN PEMBAHASAN}

\subsection{Nilai Filosofis Bale Sakenem}

\subsubsection{Nilai Filosofis Tata Letak Bale Sakenem}

Nilai filosofis Bale Dangin Sakenem dapat ditinjau dari tata letaknya dalam pengider-ider (posisi para dewa pada sembilan arah mata angin). Bale Dangin terletak pada bagian timur (kangin) suatu pekarangan atau natah (Anon., t.thn.) . Arah timur merupakan sthana Dewa Iswara, dengan atribut aksara $S a$ dan warna putih, dan merupakan mandala dengan nilai Madyaning Utama. Letak bale dangin berdekatan dengan tempat suci keluarga yang disebut sanggah atau merajan, sehingga lebih sering difungsikan sebagai bangunan untuk melaksanakan upacara agama atau yadnya pada tingkat keluarga, namun pada beberapa kasus, bale dangin juga dapat berfungsi sebagai tempat tidur. (Adhimastra, 2019). 
Nilai filosofis yang ditemukan pada objek-objek yang diamati.

Objek 1 Bale Sakanem milik Made Lokan
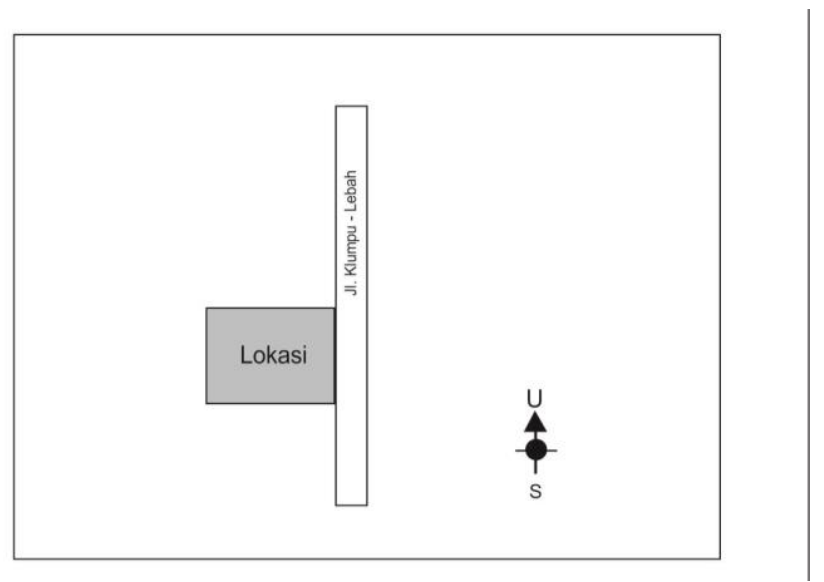

Gambar 4.1

Peta Lokasi Bale Saka Nem Milik Made Lokan.

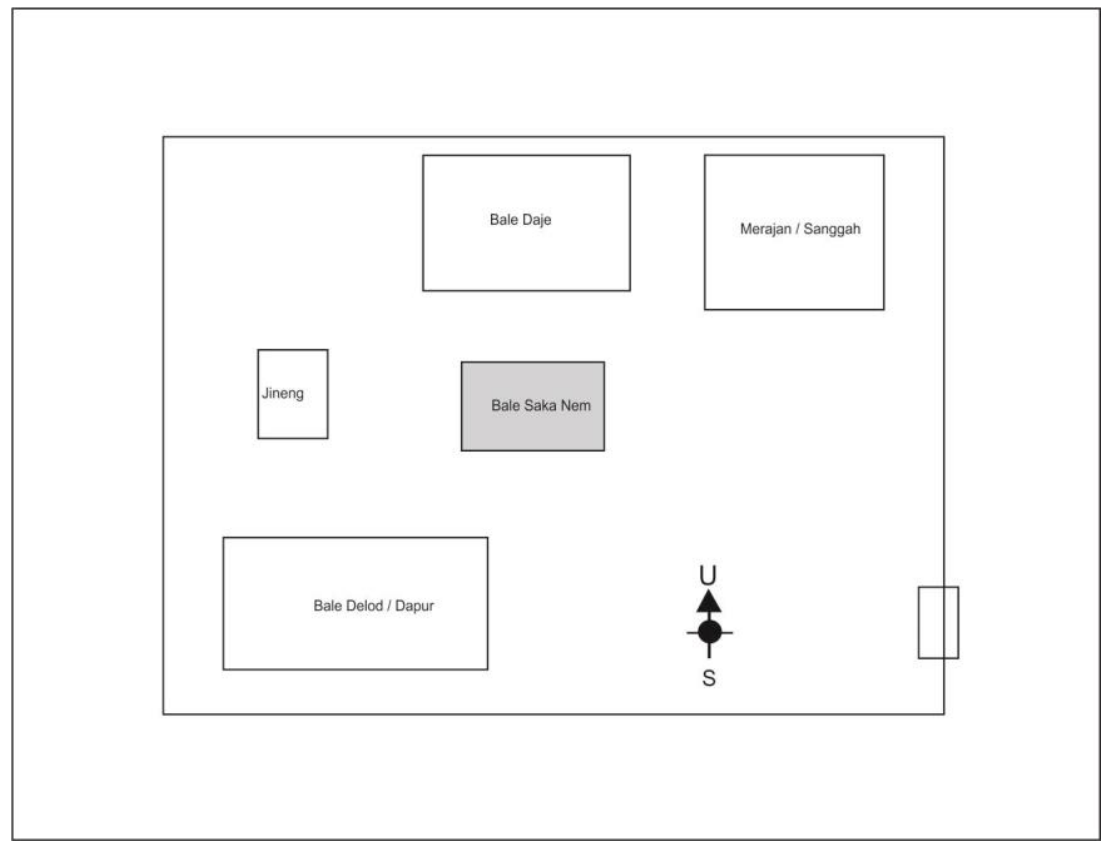

Gambar 4.2

Tata Letak Bale Saka Nem Milik Made Lokan 
Objek 2 Bale Saka Nem Milik I Made Budiana

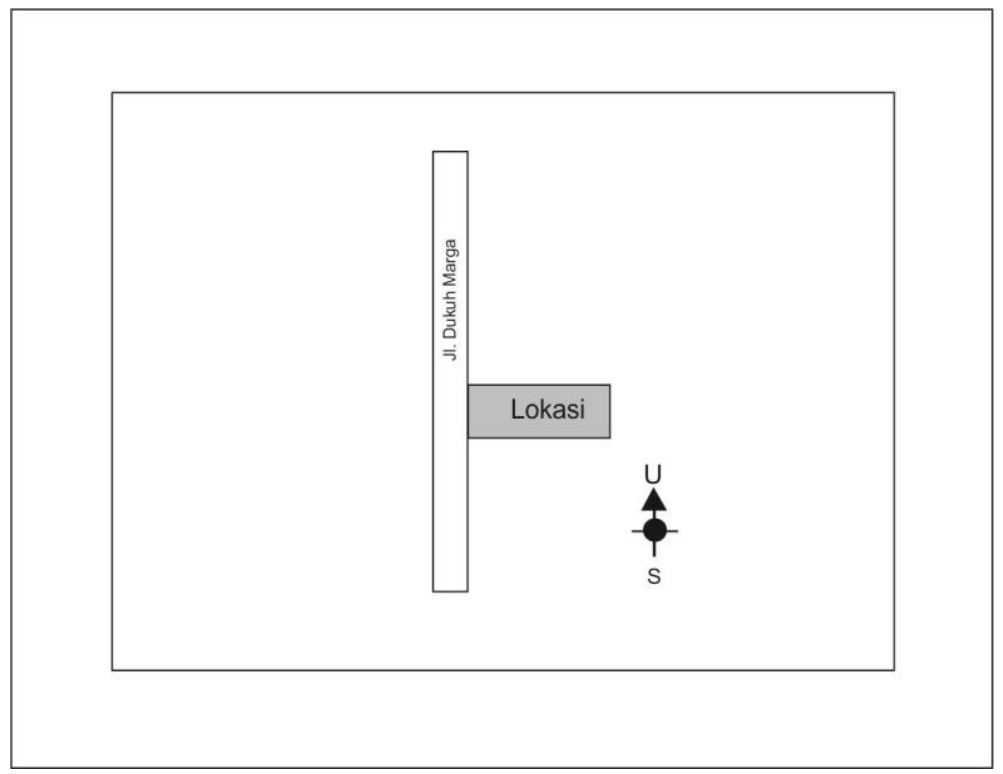

Gambar 4.3

Peta lokasi Bale Saka Nem Milik I Made Budiana Br. Tengah, Ds. Marga Dajan Puri, Kec. Marga - Tabanan

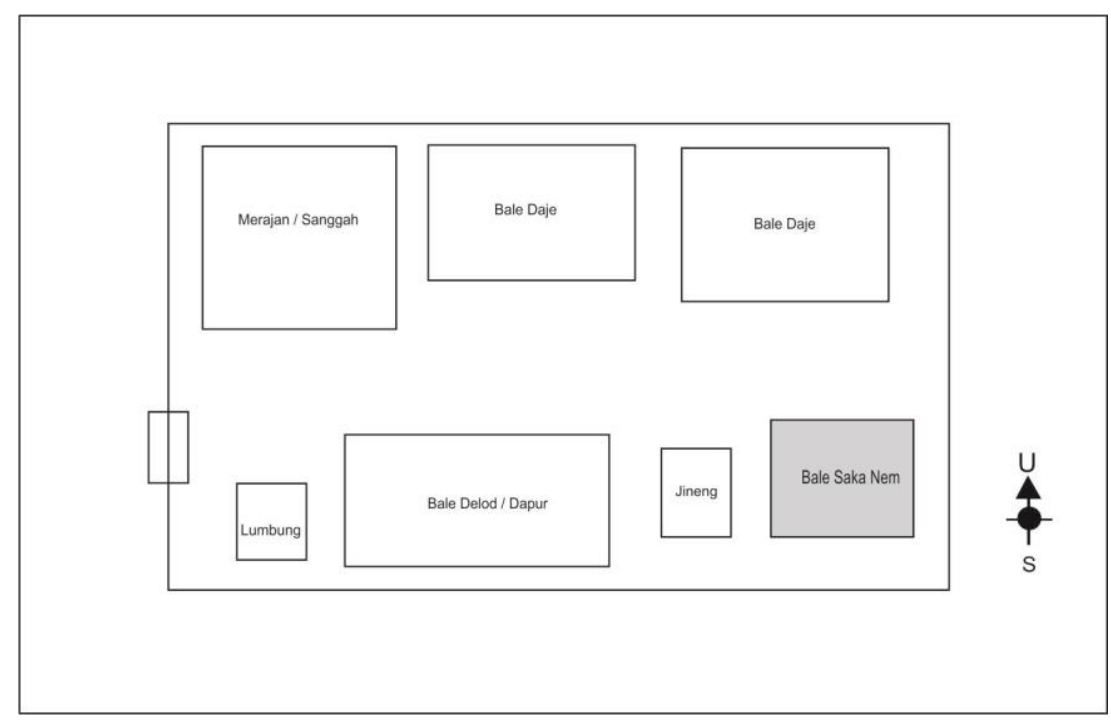

Gambar 4.4

Peta lokasi Bale Sakanem Milik I Made Budiana Br. Tengah, Ds. Marga Dajan Puri, Kec. Marga - Tabanan 
Perbandingan antara nilai filosofis tata letak dengan aplikasi pada objek yang diamati dapat dilihat pada tabel berikut ini.

\begin{tabular}{|l|l|l|l|l|}
\hline No. & Nilai Filosofis & Objek 1 & Objek 2 & Pembahasan \\
\hline 1 & Tata Letak & $\begin{array}{l}\text { Terletak pada bagian } \\
\text { timur natah di } \\
\text { sebelah selatan bale } \\
\text { daja dan sanggah } \\
\text { timur natah di } \\
\text { sebelah selatan bale } \\
\text { daja. }\end{array}$ & $\begin{array}{l}\text { Terletak pada bagian } \\
\text { terletak pada posisi } \\
\text { barat laut (kaja kauh), } \\
\text { atau di pinggir jalan. } \\
\text { Posisi sanggah ini } \\
\text { berbeda dengan lontar } \\
\text { Asta Kosali, namun } \\
\text { tidak salah karena } \\
\text { merupakan desa- } \\
\text { kala-patra yang } \\
\text { berlaku setempat. }\end{array}$ \\
\hline 2 & Fungsi & $\begin{array}{l}\text { Sebagai tempat } \\
\text { pelaksanaan upacara } \\
\text { dan tempat tidur }\end{array}$ & $\begin{array}{l}\text { Sebagai tempat } \\
\text { pelaksanaan upacara } \\
\text { dan tempat tidur }\end{array}$ & $\begin{array}{l}\text { Fungsi sesuai dengan } \\
\text { nilai filosofis yang } \\
\text { terdapat pada lontar. }\end{array}$ \\
\hline
\end{tabular}

\subsubsection{Nilai Filosofis Bentuk Bangunan Bale Sakenem}

Nilai filosofis bentuk bangunan tercermin dalam konsep Tri Angga (tiga badan), yang menekankan pada tiga nilai fisik, yaitu: Utama Angga (kepala), Madya Angga (badan) dan Nista (kaki). Aplikasi nilai filosofis dapat dilihat pada bagian-bagian bentuk bangunan tradisional Bali, yaitu atap (upper structure) sebagai kepala, konstruksi tiang (super structure) sebagai badan dan bataran/dasar bangunan (sub structure) sebagai kaki.

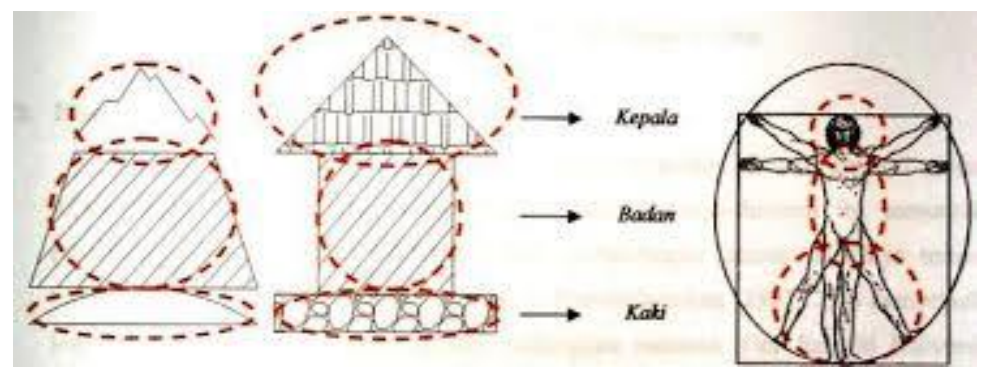

Gambar 4.5

Gambar Konsep Tri Angga

Nilai filosofis yang ditemukan pada objek-objek yang diamati.

\section{Objek 1 Bale Sakanem milik Made Lokan}




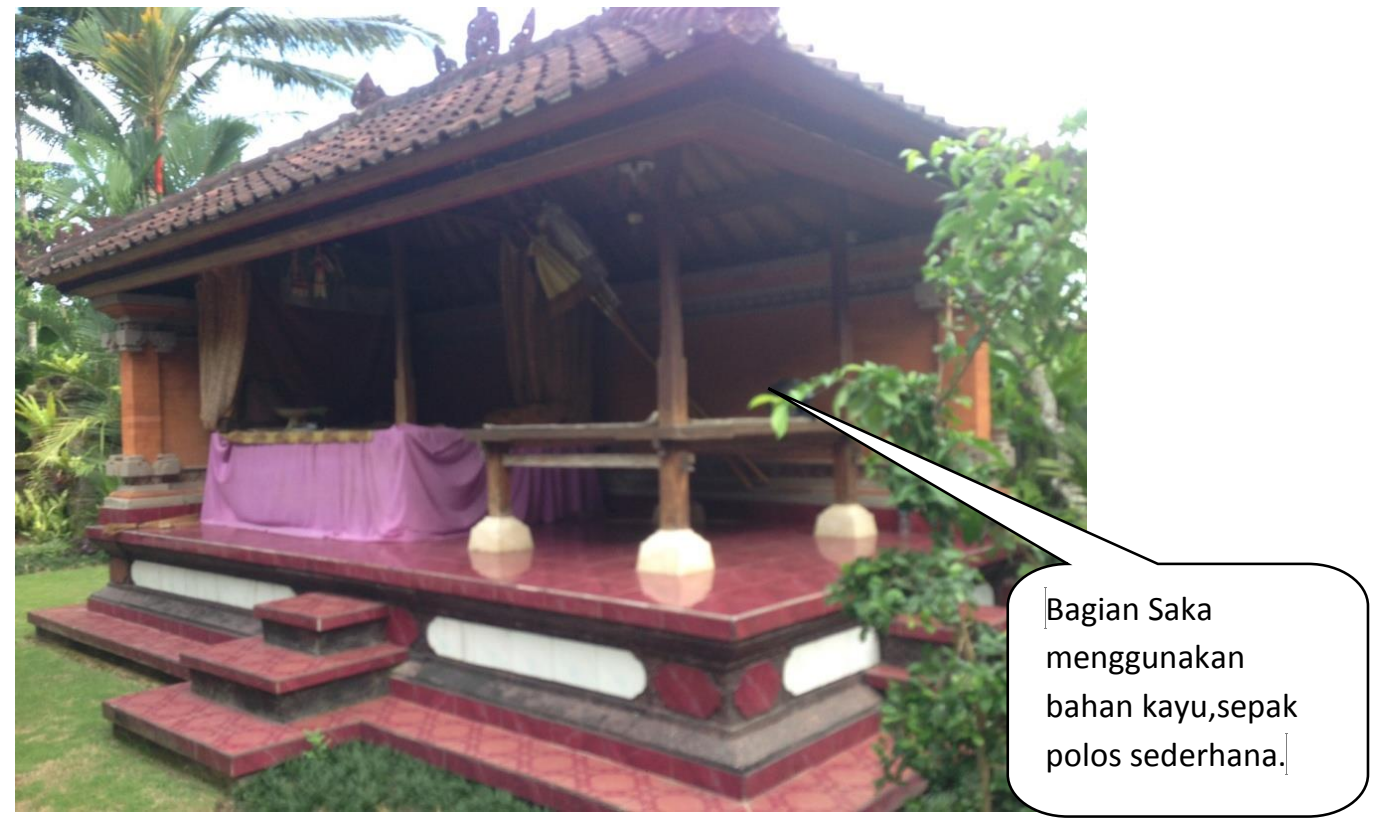

Gambar 4.5

Foto Bale Sakanem Milik Made Lokan

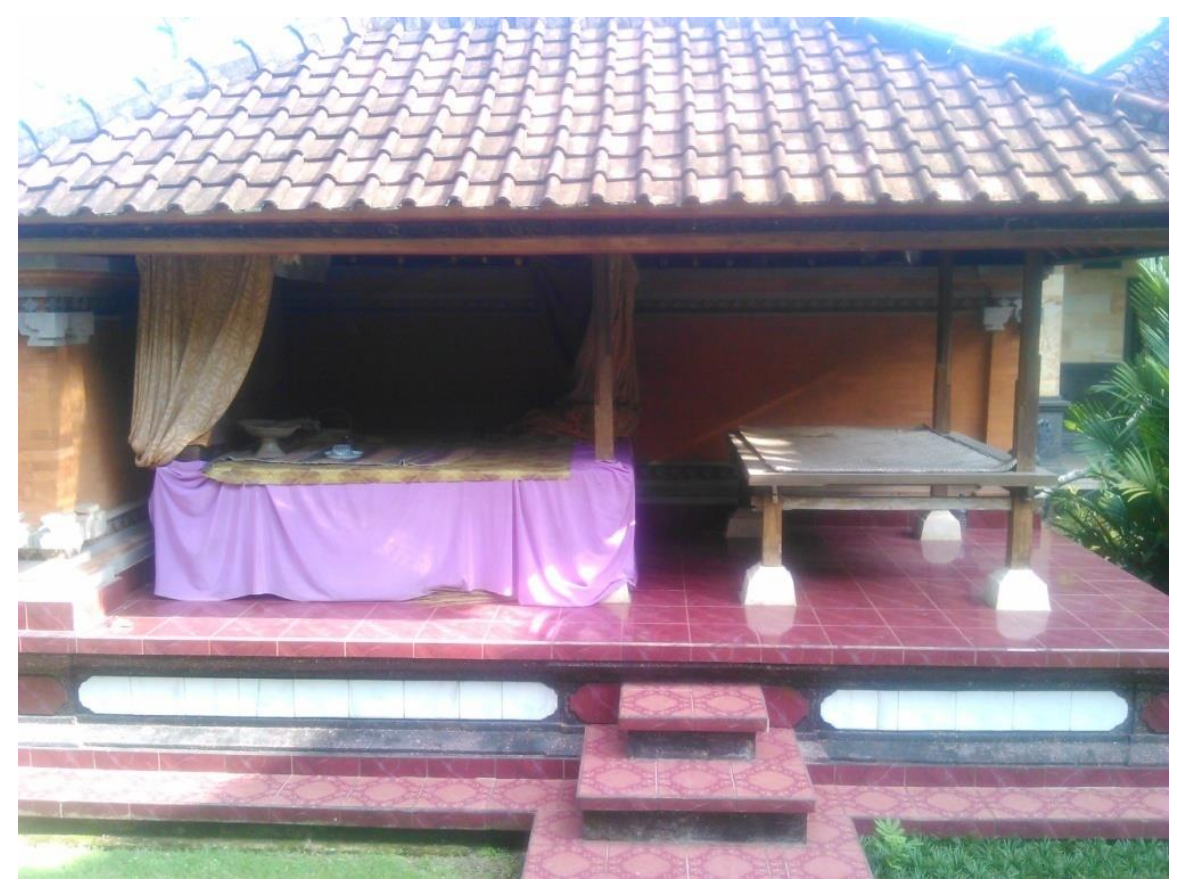

Gambar 4.6 (Tampak Depan)

Foto Bale Sakanem Milik Made Lokan 


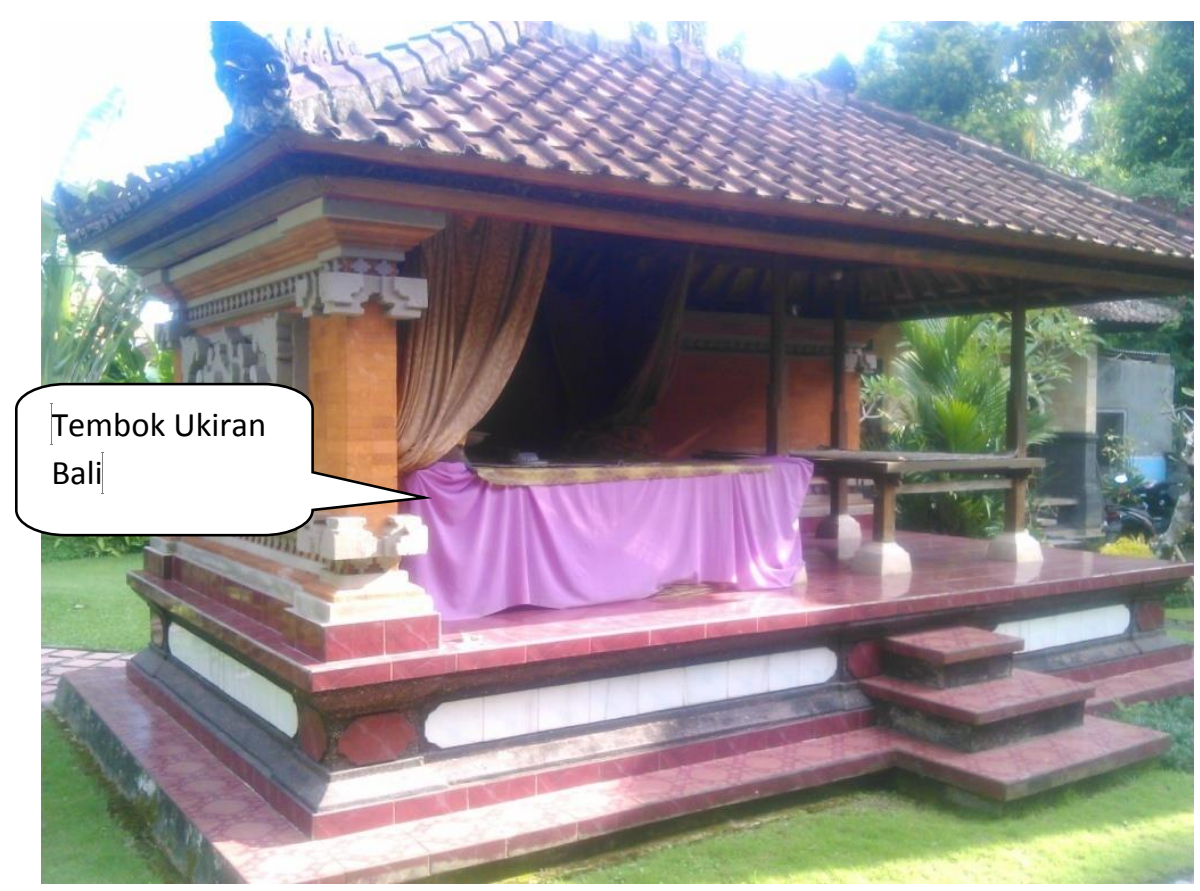

Gambar 4.7 (Tampak Samping)

Foto Bale Sakanem Milik Made Lokan

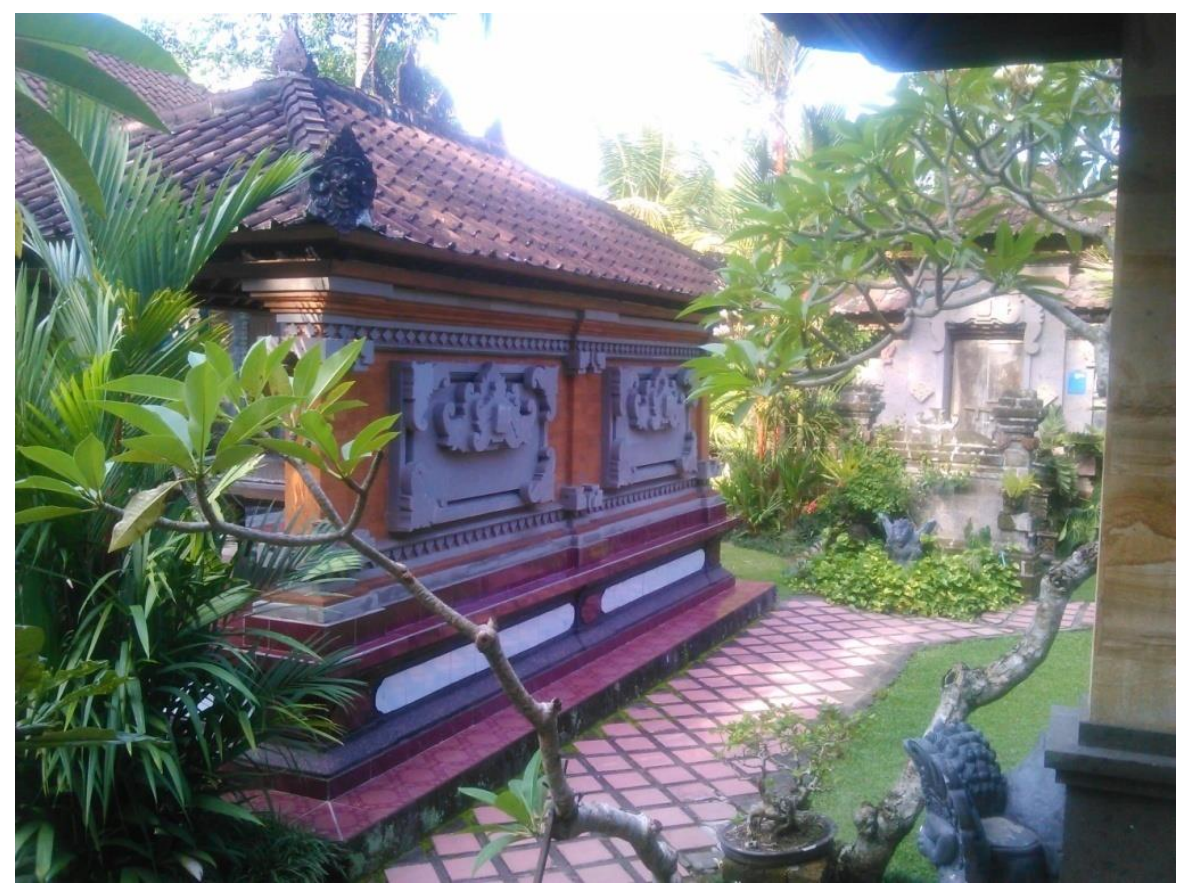

Gambar 4.8 (Tampak Samping)

Foto Bale Sakanem Milik Made Lokan 
Objek 2 Bale Sakanem milik I Made Budiana

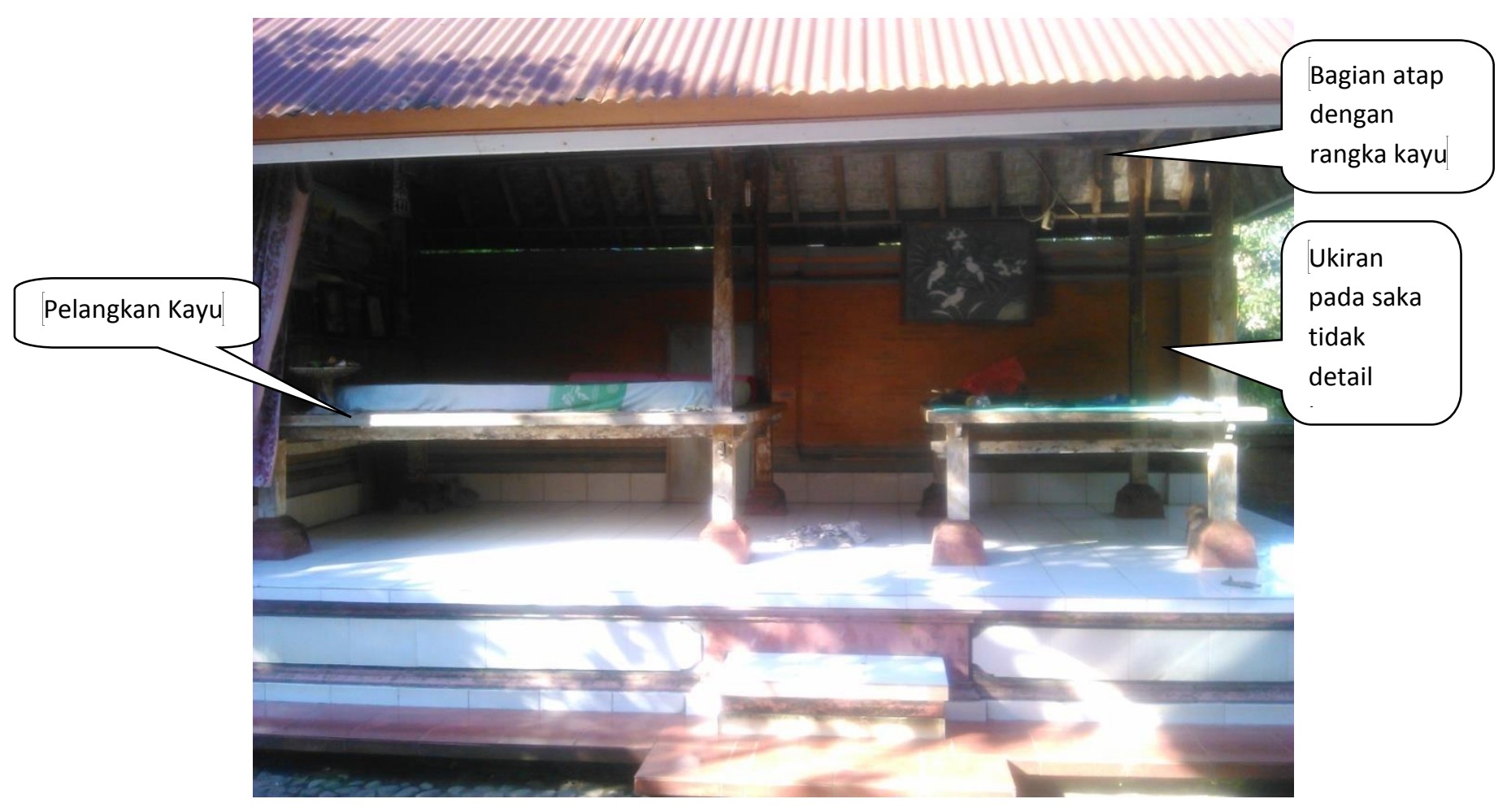

Gambar 4.9

Foto Tampak Depan Bale Sakanem Milik I Made Budiana

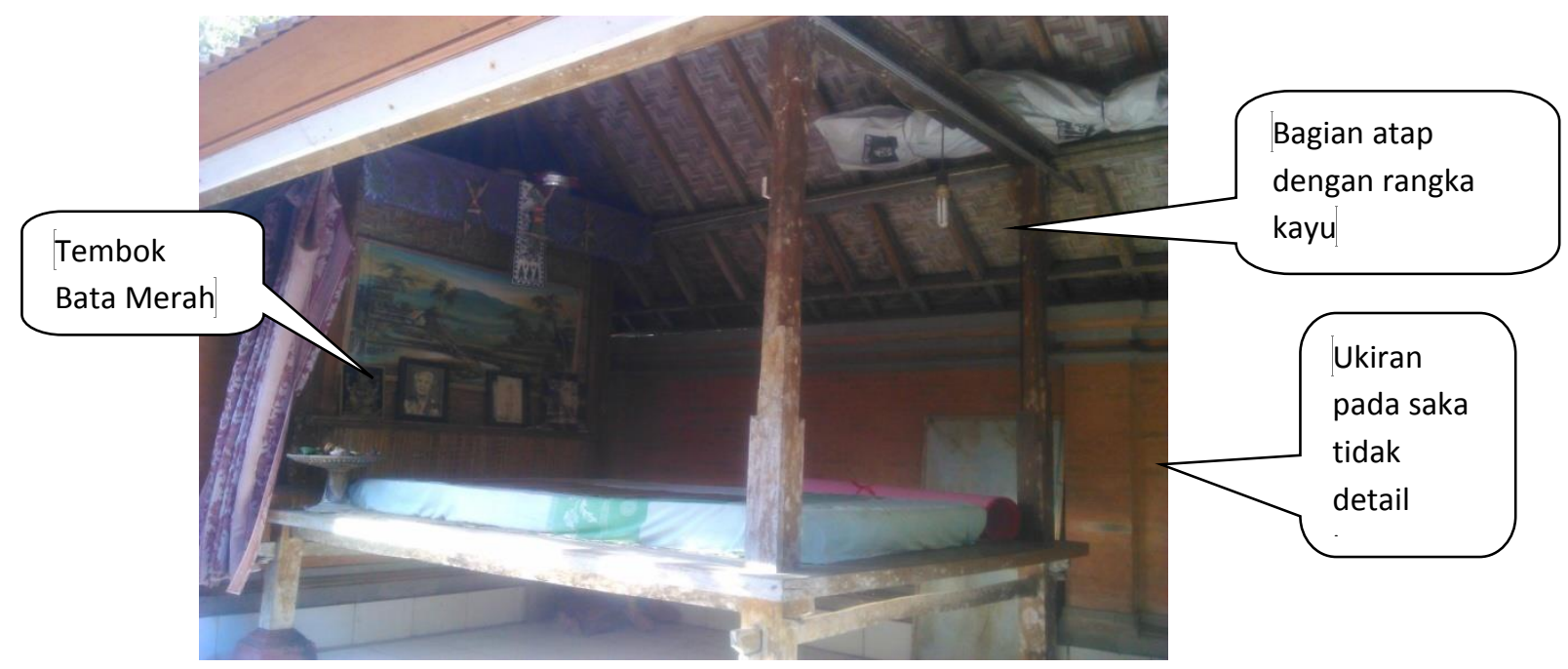


Gambar 4.10

Tampak Samping Bale Sakanem Milik I Made Budiana

Perbandingan antara nilai filosofis bentuk dengan aplikasi pada objek yang diamati dapat dilihat pada tabel berikut ini.

\begin{tabular}{|l|l|l|l|l|}
\hline No. & $\begin{array}{l}\text { Nilai } \\
\text { Filosofis }\end{array}$ & Objek 1 & Objek 2 & Pembahasan \\
\hline 1 & Bentuk & $\begin{array}{l}\text { Terbagai atas kepala, } \\
\text { badan, kaki sesuai dengan } \\
\text { konsep Tri Angga }\end{array}$ & $\begin{array}{l}\text { Terbagai atas kepala, } \\
\text { badan, kaki sesuai } \\
\text { dengan konsep Tri } \\
\text { Angga }\end{array}$ & $\begin{array}{l}\text { Sesuai Konsep Tri Angga } \\
\text { kngan }\end{array}$ \\
\hline
\end{tabular}

\subsection{Nilai Etika Bale Sakenem}

Etika dalam Arsitektur tradisional Bali mencakup kaidah-kaidah dan tata cara tentang apa yang harus dilakukan dan/atau dihindari dalam proses pembangunan suatu bangunan. Tata cara pembangunan meliputi: pemilihan lahan, kaidah pemilihan dan pengolahan bahan, kaidah dimensi dan ukuran serta kaidah konstruksi.

\subsubsection{Nilai Etika Proses Pembangunan}

Pembangunan rumah tradisional Bali dilakukan dengan secara berurutan dari bangunan satu ke bangunan yang lainnya. Terdapat 2 alternatif urutan pembangunan.

\section{Urutan Pembangunan Alternatif 1}

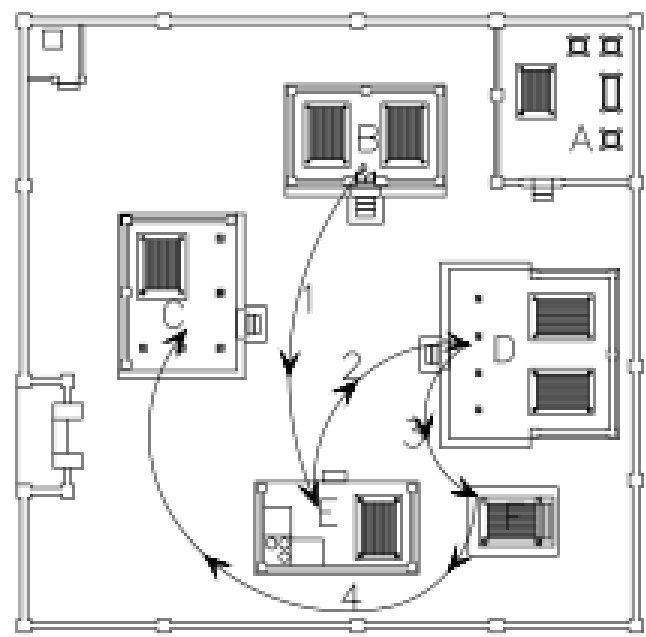

\section{Keterangan :}

A. Sanggah

B. Meten

C. Bale Dauh

D. Bale Dangin

E. Dapur

F. Lumbung

Gambar 4.12

Urutan Pembangunan Alternatif 1 
Urutan pembangunan dari massa-massa bangunan :

A. Pertama :Parahyangan sebagai kepala

B. Kedua : Pawongan sebagai badan

C. Ketiga : Pelemahan sebagai kaki

- Dalam pawongan, urutan pembangunan adalah sebagai berikut:

$\sim$ Pertama :Meten ( sebab letaknya paling hulu dan untuk ruang tidur

$\sim$ Kedua :Dapur

$\sim$ Ketiga :Bale Dangin

$\sim$ Keempat :Lumbung

$\sim$ Kelima :Bale Dauh

\section{Urutan Pembangunan Alternatif 2}

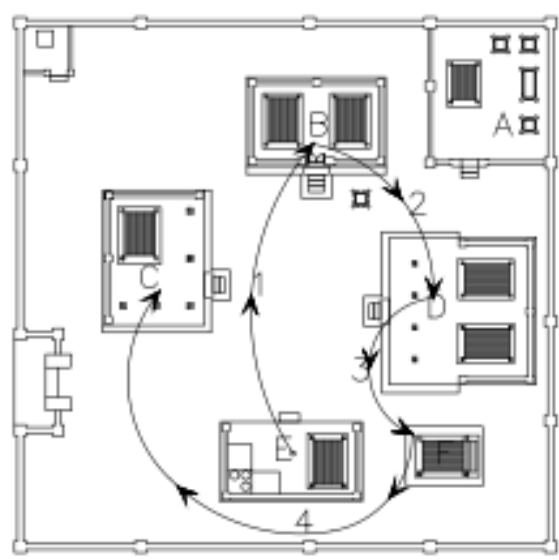

Keterangan :

A. Sanggah

B. Meten

C. Bale Dauh

D. Bale Dangin

E. Dapur

F. Lumbung

Gambar 4.13

Urutan Pembangunan Alternatif 2

Pendapat lain dari urutan pembangun pawongan:

Pertama Dapur ( sebab untuk aktivitas memasak).

- Kemudian:

-Meten.

-Bale Dangin.

-Lumbung .

-Bale Dauh. 


\section{Urutan Pembangunan Objek 1 dan Objek 2}
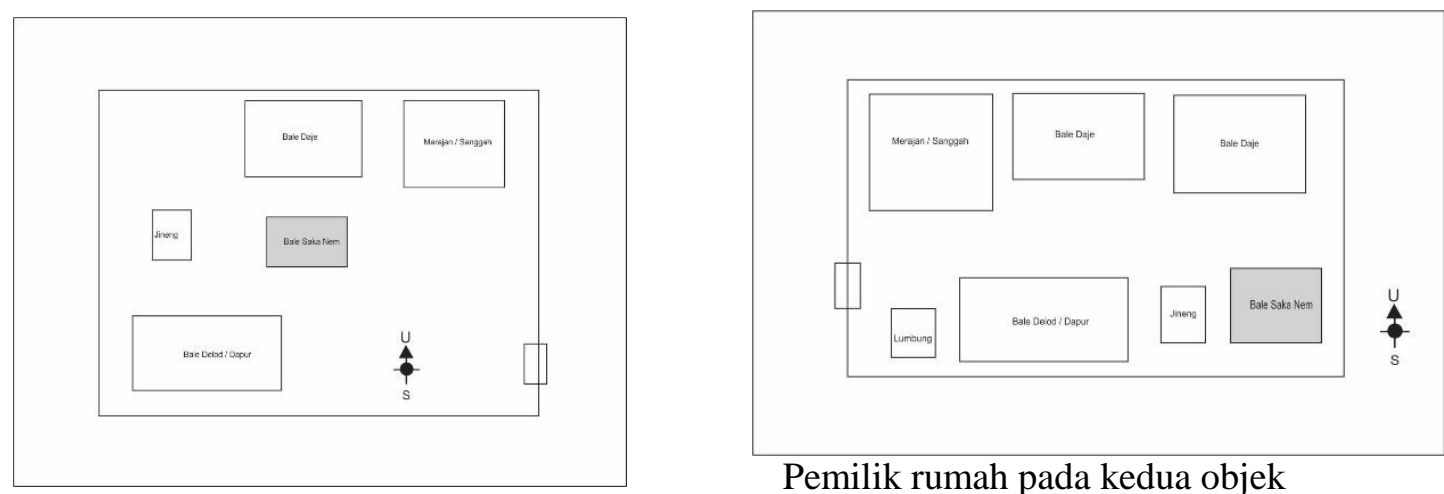

yang diamati tidak mengetahui bagaimana urutan pembangunan, dikarenakan kedua objek merupakan rumah warisan.

\begin{tabular}{|l|l|l|l|l|}
\hline No. & Nilai Etika & Objek 1 & Objek 2 & Pembahasan \\
\hline 1 & $\begin{array}{l}\text { Urutan } \\
\text { Pembangunan }\end{array}$ & Tidak diketahui & Tidak diketahui & - \\
\hline
\end{tabular}

\subsubsection{Etika Dimensi Ruang dan Bangunan}

Dimensi dalam Arsitektur Tradisional Bali menggunakan sikut yang menggunakan ukuran badan manusia. Ukuran tersebut dapat dilihat pada gambar di bawah ini.

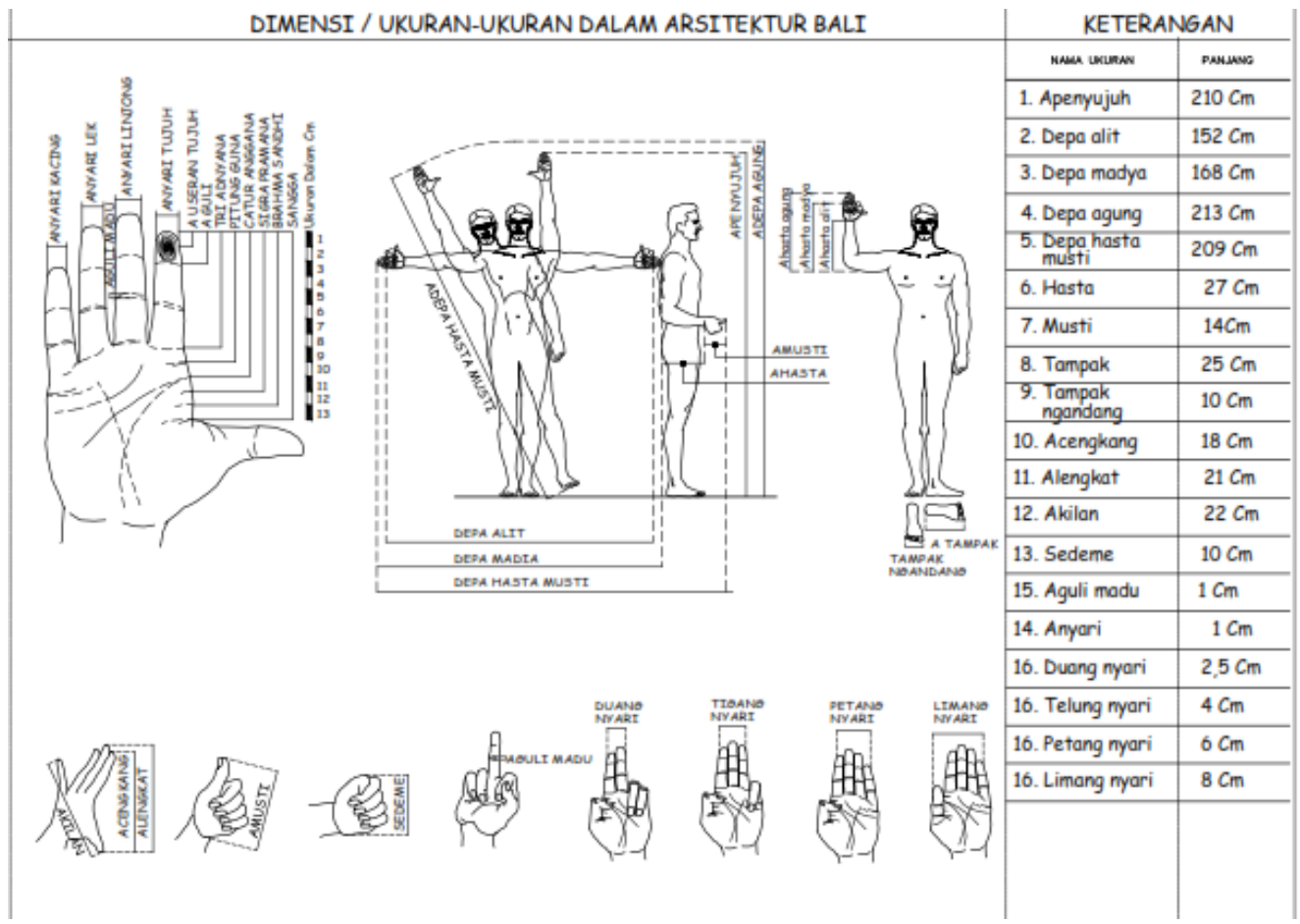

Gambar 4.14

Dimensi pada Arsitektur Tradisional Bali 


\subsubsection{Etika Dimensi/Jarak Bale Sakenemen dengan Bangunan Lain.}

Pengukuran jarak antar bangunan pada rumah tradisional Bali menggunakan perhitungan astawara

- UNTUK PARAHYANGAN
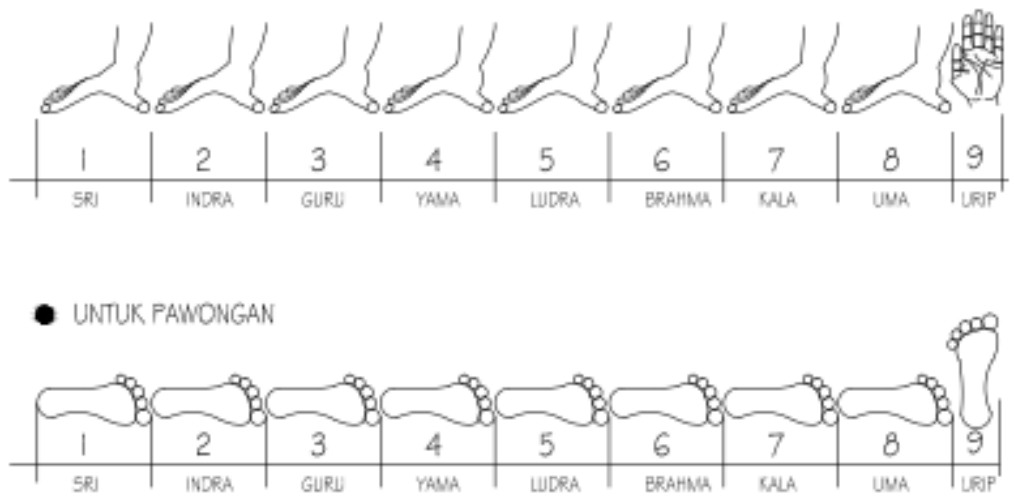

Gambar 4.15

Ukuran jarak antar bangunan pada Arsitektur Tradisional Bali

Perhitungan jarak antar bangunan untuk parahyangan/tempat suci menggunakan sikut/ukuran alengkat dan pengurip/penambah limang cari, sedangkan perhitungan jarak antar bangunan untuk pawongan menggunakan sikut/dimensi tampak dan pengurip/penambah atampak ngandang. (Asta Kosali).

Perhitungan untuk mencari jarak/posisi bale sakenem dapat dilakukan melalui 2 cara, yaitu dengan menghitung jarak bangunan meten/bale daja menuju dasar bangunan bale sakenem dan menggunakan sikut natah, yaitu dengan cara menghitung jarak dari bale dauh menuju bale sakenem atau dari jineng/lumbung menuju bale sakenem dan dari jarak 


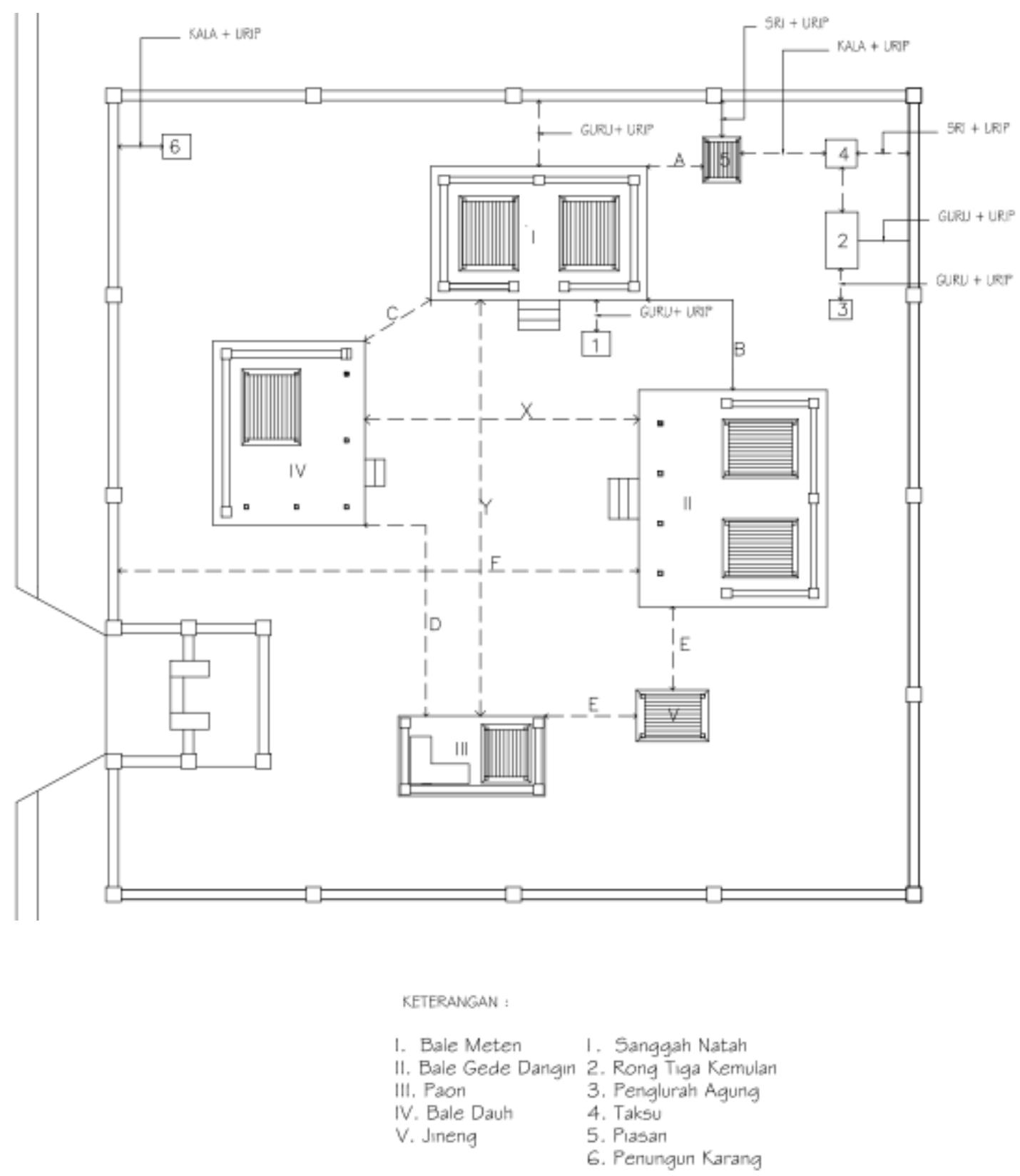

Gambar 4.16

Jarak Antar Bangunan

A. Dari meten menuju piasan perhitungan jatuh pada guru.

$(3,11,19, \ldots$.tampak + urip tampak ngandang $)$

B. Dari bale meten ke bale dangin, perhitungannya jatuh pada indra.

$(2,10,18, \ldots$ tampak + urip $)$

C. Dari bale meten nyirang ke bale dauh perhitungannya jatuh pada kala. 


$$
(7,15,23, \ldots \text { tampak + urip })
$$

D. Dari bale dauh ke paon, perhitungannya jatuh pada brahma.

$$
(6,14,22, \ldots \text { Tampak + urip })
$$

E. Dari paon dan bale gede ke jineng, perhitungannya jatuh pada sri. $(1,9,17, \ldots$ tampak + urip $)$

F. Dari as tembok sisi barat ke bale dangin, perhitungannya jatuh pada kala. ( 40, 48, 56, ... Tampak + urip )

Perhitungan dengan Tampakan dengan pelebih atampak ngandang,dihitung dari pinggir lantai Bale dangin ke barat menuju Bale dauh ( X )

1. Tampak Eka Lingga ( rumah ratu )

2. Tampak Dwi sari ( rumah pegawai, guru, pande )

3. Tampak tri gunung ( rumah petani, tonya, kebuyutan )

4. Tampak catur negara ( rumah nelayan)

5. Tampak panca kesuma ( rumah prebekel, dalang)

6. Tampak sad gadarba ( rumah naga )

7. Tampak sapta singa ( rumah mantri, pandita)

8. Tampak asta pandita ( rumah brahmana )

9. Tampak nawa tawang ( pangasturan kahyangan )

Perhitungan dengan Tampakan dengan pelebih atampak ngandang,dihitung dari pinggir lantai tempat tidur ke selatan menuju Paon ( Y )

1. Tampak bale banyu (kedatangan tamu )

2. Tampak sanggar waringin ( bersatu sanak keluarga )

3. Tampak gedong pesimpenan ( baik, kaya )

4. Tampak macan pancuran ( difitnah)

5. Tampak gajah palusungan ( baik tetapi sering didatangi pencuri )

6. Tampak warak karuron ( sering cekcok)

7. Tampak gedang punggul ( kematian ) 


\section{Dimensi antar bangunan pada Objek 1}

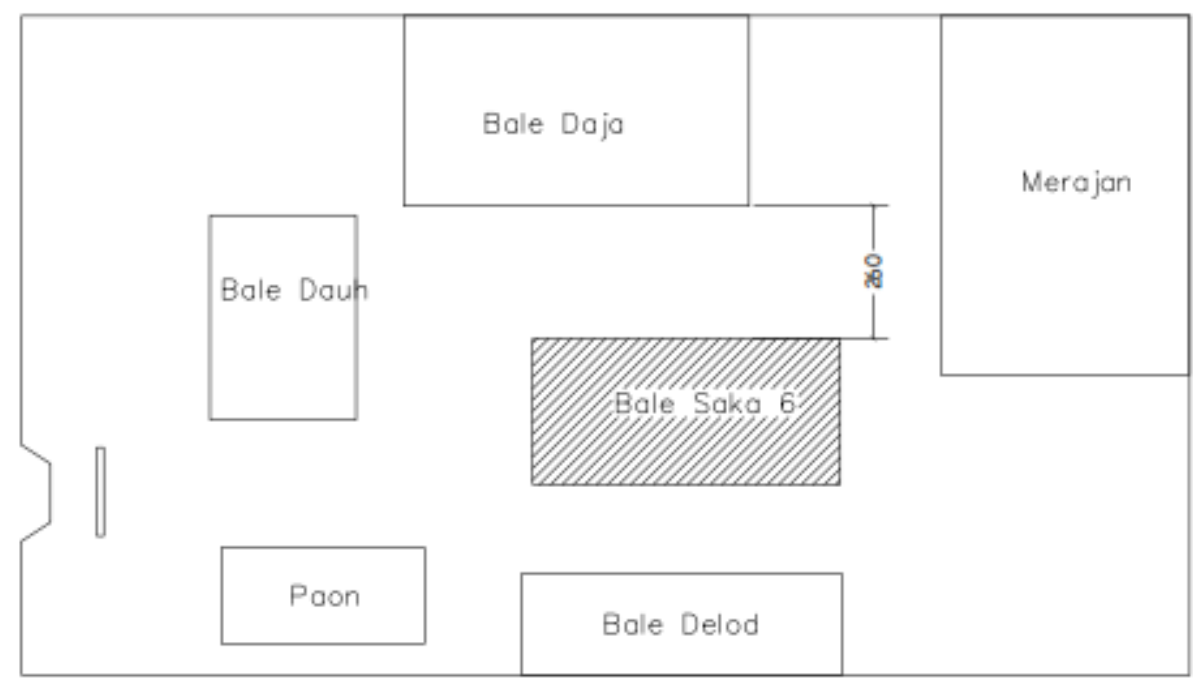

Posisi penempatan bale sakanem pada objek 1 diukur dari dasar bangunan bale daja/bale meten. Ukuran yang diperoleh adalah $260 \mathrm{~cm}$, jika dikurangi pengurip atampak ngandang $(10 \mathrm{~cm})$, maka diperoleh ukuran $250 \mathrm{~cm}$ dibagi ukuran tampak ngandang $(10 \mathrm{~cm})$, hasilnya adalah 10 tampak yang perhitungannya jatuh pada Indra.

\section{Dimensi antar bangunan pada Objek 2}

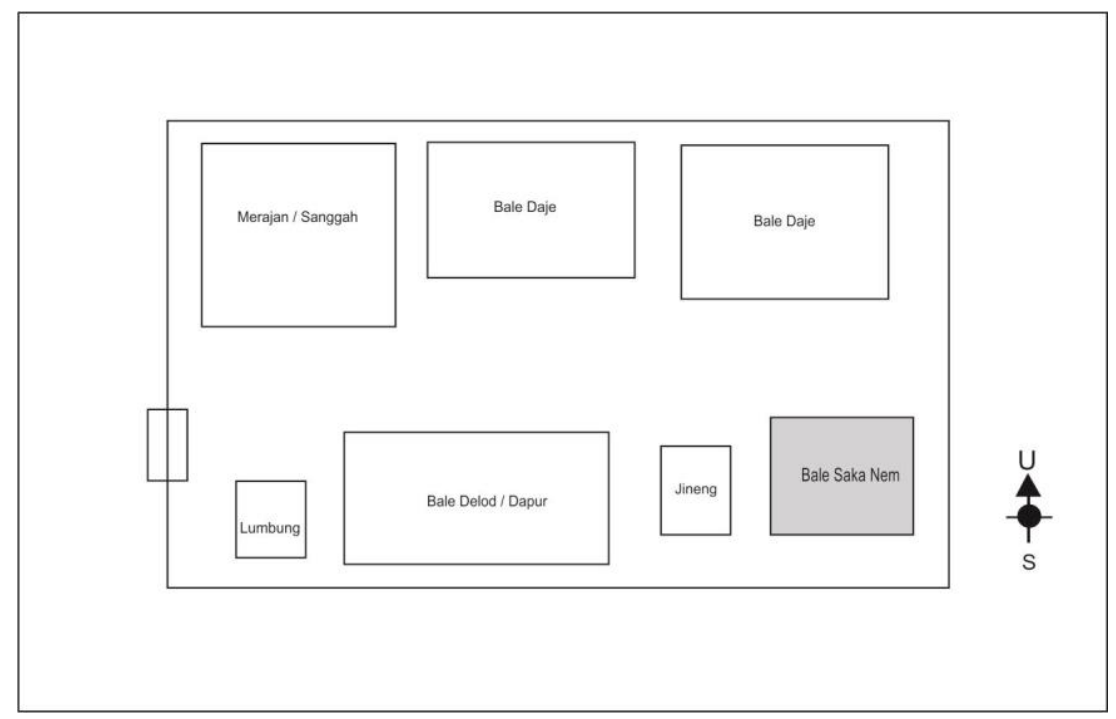

Posisi penempatan bale sakanem pada objek 2 berbeda dengan posisi penempatan seperti disebutkan dalam Lontas Asta Kosali. 


\begin{tabular}{|l|l|l|l|l|}
\hline No. & Nilai Etika & Objek 1 & Objek 2 & Pembahasan \\
\hline 1 & $\begin{array}{l}\text { Posisi/jarak } \\
\text { antar } \\
\text { bangunan }\end{array}$ & $\begin{array}{l}10 \text { tampak ditambah } \\
\text { pengurip 1 tampak }\end{array}$ & $\begin{array}{l}\text { Posisi berbeda } \\
\text { dengan lontar Asta } \\
\text { Kosali }\end{array}$ & $\begin{array}{l}\text { Perhitungan pada objek } \\
1 \text { jatuh pada Indra }\end{array}$ \\
\hline
\end{tabular}

\subsubsection{Etika Dimensi Bangunan Bale Sakenem.}

Dimensi ruang dan bangunan bale sakenem juga menggunakan sikut seperti terlontar dalam Lontar Asta Kosali. Sikut-sikut yang digunakan dalam dimensi bangunan dapat dilihat pada gambar di bawah ini.

\begin{tabular}{|c|c|c|c|}
\hline DIMENSI, PERHITUNGAN DAN BAHAN & NAMA UKURAN & NILAI & KETERANGAN \\
\hline 1. Ukuran Rai sakaffe & Catur Anggana & & $\begin{array}{l}\text { Baik untuk } \\
\text { bale }\end{array}$ \\
\hline 2. Tinggi saka 21 Rai + pengurip Anyari Kacing & Betara Asih & Utama & \\
\hline 3. Tinggi bataran 9 Deme, jatuh pada hitungan Gunung & Gunung & & \\
\hline $\begin{array}{l}\text { 4. Banyaknya anak tangga }=3 \text { buah jatuh pada hitungan gunung } \\
\text { - Lebar undag = atampak + atampak ngandang }=32 \mathrm{~cm}\end{array}$ & Gunung & & \\
\hline 5. Lebar tepas hujan alengkat +3 Nyari $=26 \mathrm{~cm}$ & & & \\
\hline
\end{tabular}

\begin{tabular}{|l|l|l|l|l|}
\hline No. & Nilai Etika & Objek 1 & Objek 2 & Pembahasan \\
\hline 1 & $\begin{array}{l}\text { Ukuran } \\
\text { Saka/tiang }\end{array}$ & $10 \mathrm{~cm}=1 \mathrm{rai}$ & $10 \mathrm{~cm}=1 \mathrm{rai}$ & $\begin{array}{l}\text { Sesuai dan baik } \\
\text { untuk bale }\end{array}$ \\
\hline 2 & Tinggi Saka/tiang & $\begin{array}{l}200,81 \quad \mathrm{~cm}, \\
\text { mendekati 21 rai } \\
(210 \mathrm{~cm})\end{array}$ & $\begin{array}{l}200,50 \mathrm{~cm}, \\
\text { mendekati 21 rai } \\
(210 \mathrm{~cm})\end{array}$ & $\begin{array}{l}\text { Mendekati sikut } \\
\text { tinggi saka }\end{array}$ \\
\hline 3 & $\begin{array}{l}\text { Tinggi Bataran 9 } \\
\text { deme }(81 \mathrm{~cm})\end{array}$ & $\begin{array}{l}71,4 \mathrm{~cm}, \text { hanya } 8 \\
\text { deme }\end{array}$ & $\begin{array}{l}80 \mathrm{~cm}, \text { mendekati } 9 \\
\text { deme }\end{array}$ & $\begin{array}{l}\text { Mendekati sikut } \\
\text { tinggi bataran }\end{array}$ \\
\hline 4 & $\begin{array}{l}\text { Banyak anak } \\
\text { tangga }\end{array}$ & $\begin{array}{l}3 \text { anak tangga, } \\
\text { Lebar undag } 33 \\
\mathrm{~cm}\end{array}$ & $\begin{array}{l}3 \text { anak tangga, } \\
\text { Lebar udang 32 cm }\end{array}$ & Sesuai sikut undag \\
\hline 5 & Lebar tepas hujan & $33 \mathrm{~cm}$ & $26 \mathrm{~cm}$ & $\begin{array}{l}\text { Mendekati sikut } \\
\text { tepas ujan }\end{array}$ \\
\hline
\end{tabular}

\subsection{Nilai Ritual Bale Sakenem}

Nilai ritual yang dimaksud di sini adalah upacara-upacara yang dilakukan dalam proses pembangunan bale sakenem 


\subsubsection{Upacara Menanggulangi Cacat Pekarangan}

Upacara ini dimaksudkan untuk menghilangkan segala bentuk baya dan bagi orang yang menempati mendapat keselamatan tanah.

1. Sajinya :

- Selembar tulisan batu bata merah dengan tulisan / dirajah dengan rajah sanghyang Candusakti

- Caru tumpeng putih kuning, ayam putih dipanggang

- Daksina, canang

2. Tata Upacara

- Terlebih dahulu bata merah dirajah dengan Sanghyang CanduSakti

- Kemudian Daksina, canang caru, tumpeng kuning, ayam putih yang telah dipanggang dihaturkan

- Setelah diberi mantram, lalu ditanam pada sudut timur laut dari pada bangunan (A)

\subsubsection{Nyukat Karang}

Upacara ini dilakukan saat akan dilakukan pengukuran lahan

1. Sarana yang diperlukan

- daksina satu

- ketipat kelanan

- canang ubungan mare repa

- peras penyeneng

- sadaan

- asep menyan api cakep

- sesantun 888 biji uang kepeng

- sesajen segan manca warna

- lekesan 5 urip

- daging ebatan babi

2. Tata Cara

- Pertama memasang patok sebagai "Guru" pada arah kaja kangin

- Selanjutnya semua sarana upacara dipersembahkan kepada bhuta kala

- Dilanjutkan pemasangan patok pada arah tenggara, barat daya dan barat laut.

- Segala sarana upacara dihaturkan dengan disertai pengukuran dimulai dari Bale Daja ke Bale Dauh dan Dapur, dihitung dengan telapak kaki

\subsubsection{Upacara Nyapuh Karang}

Nyapuh diperuntukan bagi sawah dan tegalan serta pekarangan tujuannya adalah menetralkan tempat dari gangguan baik sekala maupun niskala, kramaning nunas tirta ring pura Puseh, Dalem, Desa ke Surya.

1. Sarana

- 1 buah Daksina

- Tipat kelan

- Nasi ireng

- Ulam bawang jahe

2. Tata Cara

- Ngambil tanah di luanan mewadah Tipat Dampul asiki

- Malih ngambil ring teben mewadah Tipat Nasi asiki

- Nanceb Sanggah Cucuk

- Ngunggahan dumun ring sanggah punika gantungan tipat 


\subsubsection{Upacara Nyakap Karang} dibangun.

Upacara nyakap karang bertujuan untuk merpesatukan tanah atau lahan yang akan

1. Sarana

- Sanggar Tutuan

- Suci asoroh genep

- Guling bebek

- ring sor Sesayut Pengambean Pengulapan

- Peras Penyeneng

- Sodaan

- Penebusan Gelar Sanga

- Pemangguh Pemali

- 1 Segehan Agung

- 3 butir telur

- 3 buah kelapa

- Benang

2. Tata Cara

- $\operatorname{Uang}($ pipis )

- mapulang pancung

- ngambil tanah mewadah ketipat di sanggar

- raris sambehang ring sor upakara

\subsubsection{Upacara Nyukat Ngeruak dan Nasarin}

Tujuan upacara ini adalah meminta keselamatan agar tidak diganggu memohon kepada bedawang nala sebagai dewanya pertiwi agar memberikan bangunan.

1. Sarana

- Caru ayam brumbun madulurun palahyangan, sesayut durmangala prayasitamala dipersembahkan kepada sang bhuta bhuana (uang kepeng)

- Tetabuhan agung

- Tetabuhan tuak. berem, dipersembahkan kepada sang bhuta dengen

- Bata merah dirajah dengan rerajahan bedawang nala diisi tulisan ongkara

- Klungah nyuh gading (kelapa kuning) kinasturi

- Menurut wangsanya
a. Brahmana ongkara
b. Ksatria ongkara mertha
c. Wesia ongkara merta
d. Sudra ongkara

2. Tata Cara

- Caru ayam brumbunbun maduluruan palahyangan sesayut durmangala dihaturkan kepada sang bhuta buana segehan agung ditambah tetabuh arak berem dihaturkan kpd sang buta dengen

- Nyukat karang dengan berpedoman pada asta bumi

- Peletakan batu pertama (nasarin) berupa bata merah yang dirajah dg bedawang nala yang diisi ongkara di susun klungah nyuh gading bijangin wenia simurat manut wangsa

- Diisi (pulangin) wangi-wangi lenga wangi, urat wangi, pepes peras alit majinah 11 keteng, kwangen manjinah 33 keteng manut uriping buana canang satekep, tumpeng, ayam biying 


\subsubsection{Upacara Memakuh}

Upacara ini digelar agar orang yang akan tinggal di bangunan tersebut merasa aman dan tentram serta betah dan terhindar dari hal-hal yang tidak diinginkan (sakit, boros, marah, dan pertengkaran)

1. Sarana

Peras sesantun, raka buah-buahan, canang pangokas, ceniga, api cakep dupa, segehan dan air suci

2. Tata Cara

Percikan 3 x air suci pd kerangka bangunan, lalu haturkan sarana upacara disertai dg mantra

\subsubsection{Upacara Memasang Usuk Dan Mengatapi}

Tujuan dari upacara ini adalah agar atap menjadi kuat dari pengaruh cuaca

1. Sarana

Tirta (air suci) daksina peras, sajeng, tepung tawar

2. Tata Cara

Percikan tirta 3x taburkan tepung tawar lalu dikuti dengan mantram

\subsubsection{Upacara Pemelaspasan}

Setelah bangunan terbentuk tahapan terakhir adalah tahap penyelesaian dan finishing atap, dinding dan lantai bangunan. Setelah difinishing bangunan tersebut diupacarai terakhir dengan upacara Pemlaspasan. Upacara pemlaspasan ini dibagi menjadi 3 tingkatan yaitu

1. Pemlaspasan Nista

2. Pemlaspasan Madya

\section{Pemlaspasan Utama}

Sesudah melakukan upacara pemlaspasan, maka pemilik rumah sudah bisa menempati bangunan tersebut.

\begin{tabular}{|c|c|c|}
\hline Pemelaspasan & Sarana & Tata Cara \\
\hline Pemlaspasan Nista & $\begin{array}{l}\text { - banten pemlaspas adulang } \\
\text { dg ulam bebek putih } \\
\text { - ayam seplaken : luh, } \\
\text { muani, putih, kuning } \\
\text { - ayaban tumpeng } \\
\text { solas\&sorohan } \\
\text { - pengurip } \\
\text { - prayasita durmangala } \\
\text { - pengulapan }\end{array}$ & $\begin{array}{l}\text { - ngadegang betara siwa } \\
\text { tiga } \\
\text { - nunas penugrahan Guru } \\
\text { Reka, Saraswati, } \\
\text { Sanghyang wenang } \\
\text { - nunas upasaksi } \\
\text { - nguntap ida betara sami } \\
\text { saksi ke surya } \\
\text { - ngaturang pemelas tangan } \\
\text { - ngaturang pengresik, lis } \\
\text { penyeneng } \\
\text { - pekeling } \\
\text { pertiwi\&ngaturang caru }\end{array}$ \\
\hline
\end{tabular}




\begin{tabular}{|c|c|c|}
\hline Madya Pemlaspasan & 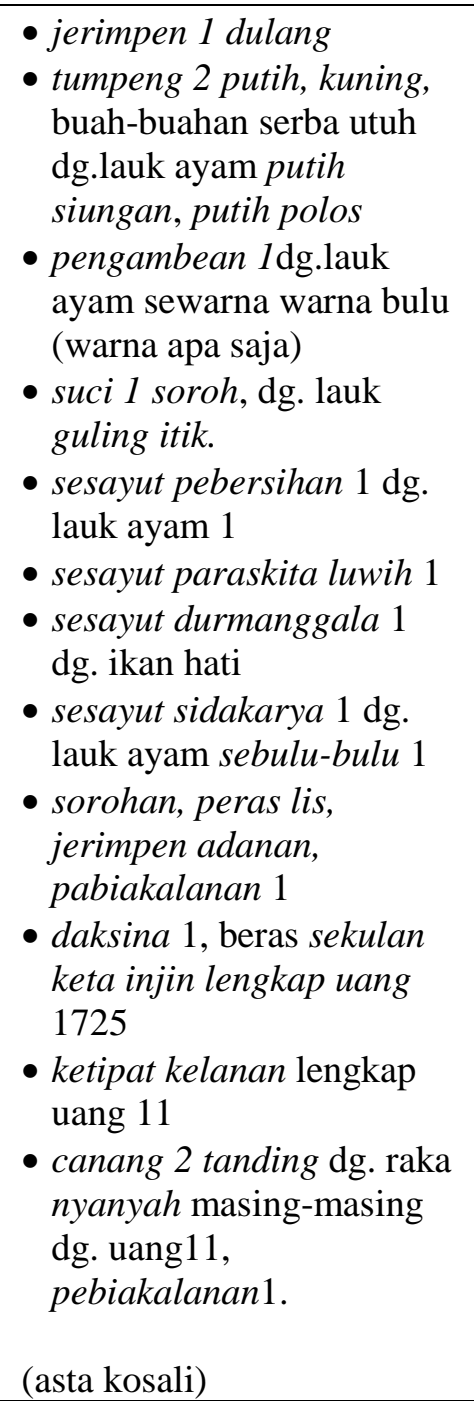 & $\begin{array}{l}\text { - memasang pada tiang yang } \\
\text { dipolesi darah ayam } \\
\text { sebagai pengurip (jiwa) } \\
\text { - kemudian dilanjutkan dg. } \\
\text { upacara melaspas } \\
\text { yg meliputi: } \\
\text { a. munggahang banten } \\
\text { b.margiang prascita } \\
\text { percikan air suci keseluruh } \\
\text { bangunan } \\
\text { c.metabuh sajeng dan } \\
\text { ngayabin } \\
\text { d.ngelis ka sury, ke banten } \\
\text { (sesajen) }\end{array}$ \\
\hline Pemlaspasan Utama & 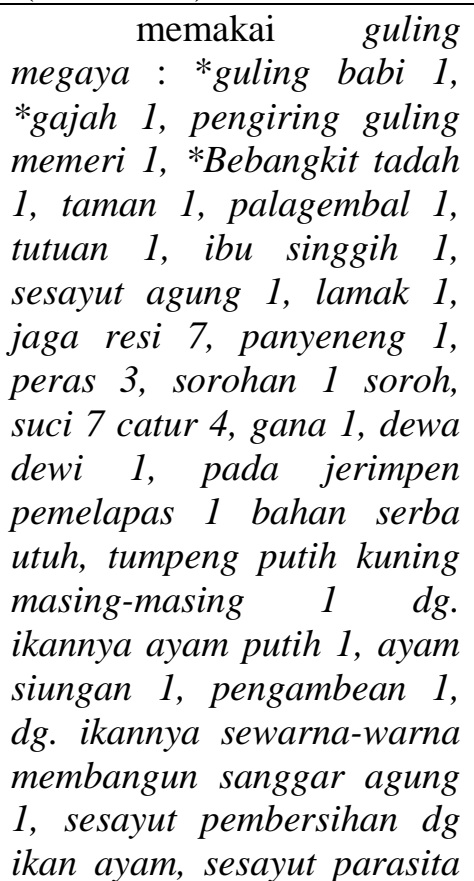 & $\begin{array}{l}\text { bila pada bale dg. lis dulu } \\
\text { memasang satsat pada tiang } \\
\text { polesi darah ayam sebagai } \\
\text { pencuri (menjiwai) } \\
\text { poleskan darah ayam pada } \\
\text { tiang, lalu laksanakan upacara } \\
\text { : } \\
\text { 1. munggahang banten } \\
\text { (sarana upacara) } \\
\text { 2. margiang parasita, } \\
\text { percikan keseluruh } \\
\text { bangunan } \\
\text { 3. metabuh sajeng dan } \\
\text { ngayabin } \\
\text { 4. ngelis kesurya, ngelis ke }\end{array}$ \\
\hline
\end{tabular}




\begin{tabular}{|l|l|c|}
\hline & $\begin{array}{l}\text { luwih, sesayut durmangala 1 } \\
\text { dg ikan ati, sesayut }\end{array}$ & banten \\
durmanggita dekali lagi ngayab dan \\
bawang jahe sereh 1, sesayut & metabuh sajeng \\
pageh urip 1 lauknya betutu & 6. yang memiliki upacara \\
ayam 1, sesayut sidakarya 1 & muspa (sembahyang) \\
dg lauk telur itik 1 ayam & \\
sudamala 1, sesayut & \\
pepajegan 1 lauknya ayam 1, & \\
sesayut melara melaradan 1 & \\
dg.lauknya udang 1, sesayut & \\
mandi sakecap 1. & daksina beras & \\
sekulak uang arta sebesar & \\
1725, ketipat kelanan 1, & \\
uang 11, canang 2 tanding, & \\
mereka nyanyah, uangnya & \\
masing 11, peras ageng 1, & \\
uang, 225 & \\
\hline
\end{tabular}

\section{PENUTUP}

Nilai filosofis bale dangin sakenem meliputi nilai tata letak, fungsi, dan bentuk. Objek yang diteliti memiliki nilai filosofis yang sesuai dengan lontar asta kosali. Nilai etika bale dangin sakenem, meliputi urutan pembangunan, posisi/jarak antar bangunan, Ukuran Saka/tiang, Tinggi Saka/tiang, Tinggi Bataran, Banyak anak tangga dan Lebar tepas hujan. Secara etika beberapa bagian bangunan Bale Dangin Sakenem baik pada objek 1 dan 2 memiliki atau mengikuti nilai etika dalam lontar Asta Kosali. Nilai ritual adalah upacaraupacara terkait yang dilakukan selama proses pembangunan, yang meliputi: Upacara Menanggulangi Cacat Pekarangan, Nyukat Karang, Upacara Nyapuh Karang, Upacara nyakap karang, Upacara Nyukat Ngeruak dan Nasarin, Upacara Memakuh, Upacara Memasang Usuk Dan Mengatapi dan Upacara Pemelaspasan (Nista, Madya dan Utama).

\section{Ucapan Terima Kasih}

Penelitian ini dapat terlaksana berkat hibah penelitian dosen pemula, yang didanai secara penuh oleh Kementrian Riset, Teknologi, dan Pendidikan Tinggi Republik Indonesia pada tahun pelaksanaan 2019. Penulisan dan penyelesaian penelitian ini, tidak terlepas atas dukungan dari Fakultas Teknik Universitas Dwijendra khususnya pada Program Studi Arsitektur yang mendukung penuh penelitian ini. Ucapan terima kasih juga diucapkan kepada Lembaga Penelitian dan Pengabdian Kepada Masyarakat Universitas Dwijendra yang telah memfasilitasi pengajuan dan pelatihan proposal penelitian sehingga penelitian ini dapat terlaksana.

\section{DAFTAR PUSTAKA}

Adhika, I. M., 1994. Peran Banjar dalam Penataan Komunitas, Studi Kasus Kota Denpasar. Bandung: Tesis Program S2 Jurusan Perencanaan Wilayah dan Kota Institut Teknologi Bandung.

Anon., n.d. Lontar Asta Kosali. s.l.:s.n.

Anon., n.d. Lontar Wiswakarma. s.l.:s.n. 
Dwijendra, N. K. A., 2008. Arsitektur Rumah Tradisional Bali. Denpasar: Udayana University Press.

Gelebet, I. N., Meganada, I. W., Negara, I. M. Y. \& Suwirya, I. M., 1986. Arsitektur Tradisional Daerah Bali. Denpasar: Departemen Pendidikan dan Kebudayaan.

Gorda, I. G. N., 1996. Etika Hindu dan Perilaku Organisasi. Singaraja: Widya Akasara Nasional.

Moleong, L. J., 2008. Metodologi Penelitian Kualitatif Edisi Revisi. Bandung: PT. Remaja Rosdakarya.

Uthama, I. B. A., 2015. Seri 1 Arsitektur Tradisional Bali, Filosofi, Konsep dan Aplikasi. Surabaya: Paramita. 